\title{
Fluorogenic Protein Probes with Red or Near-Infrared Emission for Genetically Targeted Live-Cell Imaging
}

Sylvestre P. J. T. Bachollet, Cyril Addi, Jean-Maurice Mallet, Blaise Dumat

Submitted date: 13/05/2020 Posted date: 14/05/2020

Licence: CC BY-NC-ND 4.0

Citation information: Bachollet, Sylvestre P. J. T.; Addi, Cyril; Mallet, Jean-Maurice; Dumat, Blaise (2020):

Fluorogenic Protein Probes with Red or Near-Infrared Emission for Genetically Targeted Live-Cell Imaging.

ChemRxiv. Preprint. https://doi.org/10.26434/chemrxiv.12292865.v1

A series of red-emitting and near-infrared fluorogenic protein probes based on push-pull molecular rotor structures was developed. After characterization of their optical properties using Bovine Serum Albumin as a model protein, they were conjugated to a halogenoalkane ligand in order to target the protein self-labeling tag HaloTag. The interaction with HaloTag was investigated in vitro and then the most promising probes were applied to live-cell imaging in wash-free conditions using fluorogenic and chemogenetic targeting of HaloTag fusion proteins.

File list (2)

Dumat_Fluorogens_V1.pdf (1.02 MiB)

view on ChemRxiv - download file

Dumat_Fluorogen_SI_V1.pdf (2.33 MiB)

view on ChemRxiv • download file 


\title{
Fluorogenic Protein Probes with Red or Near-Infrared Emission for Genetically Targeted Live-Cell Imaging
}

\author{
Sylvestre P. J. T. Bachollet, ${ }^{\text {a }}$ Cyril Addi, ${ }^{b}$ Jean-Maurice Mallet ${ }^{\mathrm{a}}$ and Blaise Dumat*a \\ a Laboratoire des biomolécules, LBM, Département de chimie, École normale supérieure, PSL University, Sorbonne \\ Université, CNRS, 75005 Paris, France. \\ ${ }^{\mathrm{b}}$ Membrane Traffic and Cell Division Lab, Cell Biology and Infection Department, Institut Pasteur, CNRS UMR3691, \\ Sorbonne Université, 75005 Paris. \\ *E-mail: $\underline{\text { blaise.dumat@ens.psl.eu }}$
}

\begin{abstract}
A series of red-emitting and near-infrared fluorogenic protein probes based on push-pull molecular rotor structures was developed. After characterization of their optical properties using Bovine Serum Albumine as a model protein, they were conjugated to a halogenoalkane ligand in order to target the protein self-labeling tag HaloTag. The interaction with HaloTag was investigated in vitro and then the most promising probes were applied to live-cell imaging in wash-free conditions using fluorogenic and chemogenetic targeting of HaloTag fusion proteins.
\end{abstract}

\section{Introduction}

Due to its high spatial and temporal resolutions, fluorescence imaging has become a prominent technique to observe dynamic biological processes. In parallel to instrumental development, the field has benefited from a sustained effort by chemists to develop new probes tailored for specific applications in order to decipher phenomenon of ever-increasing complexity. ${ }^{1}$ Fluorogenic probes that specifically light up upon binding to their target but are otherwise dark are of particular interest to perform targeted imaging with increased selectivity by minimizing the off-target signal. ${ }^{2,3}$ Since they do not require washing protocols to remove the excess of dye, they are in particular useful for imaging complex samples (e.g. for in vivo imaging) and should thus ideally be optimized for live imaging, with a high brightness, good cell permeation and far-red emission. The absence of autofluorescence and the lower diffusion of light make the red and near infrared (NIR) range particularly suited for in vivo imaging of thick samples. Strategies to develop fluorogenic probes involve for instance the combination of fluorophores and quenchers that are separated upon target binding, ${ }^{4,5}$ reactions that unquench a latent fluorophore (e.g. tetrazine ligation) ${ }^{6-8}$ or the isomerization of Si-Rhodamines between a dark and a fluorescent form, the latter being favoured in the hydrophobic environment of a protein. ${ }^{9,10}$ An alternative design strategy relies on the use of solvatochromic and/or molecular rotor structures such a styryl dyes and their analogs. Such molecules have flexible dipolar structures that make them intrinsically sensitive to the polarity and the viscosity of the environment. ${ }^{11,12}$ Their emission is usually negligible in water but they can become highly fluorescent upon binding to a biomolecule. Several examples exist, including DNA or protein probes for in vitro applications ${ }^{13-16}$ but, to be used in biological imaging, the probes need to react or interact specifically with a biological target, which requires careful optimization of the fluorogen/host pair for each application. This can be achieved either by highthroughput screening or more recently by directed evolution techniques to identify the cognate biomolecular host or by coupling the fluorogen to a selective targeting ligand. ${ }^{17-19}$ To advance the field of bioimaging, it is thus of great importance to develop red or NIR-emitting fluorogens that can be associated to an efficient targeting method. A versatile strategy to image proteins is to use genetically encoded protein tags that are modified enzymes able to react selectively with fluorophores bearing the substrate ligand. ${ }^{20,21}$ The prominent advantage of using such a targeting strategy is that the fluorogen only needs to be optimized for a given protein tag to then virtually target any protein of interest. The two most common tags are SNAP-tag and Halotag, that have been widely used to genetically target a variety of molecular probes. ${ }^{9,10,20,22-26}$ Only a handful of push-pull fluorogenic dyes for Halotag and SNAP-tag have however been reported. The reported dyes present limitations for in vivo imaging due to their green emission ${ }^{27-29}$ or have been designed for specific applications like protein misfolding detection. ${ }^{30,31}$ Among other examples, Zhang and coworkers tested an analog of the chromophore from the red fluorescent protein Kaede as a fluorogenic probe targeting SNAP-tag. ${ }^{32}$ However, Halotag remains to date the most useful protein tag, with very fast reaction kinetics and a chemically simple and lipophilic linker resulting in good cell permeation of the conjugates. For Halotag, a series of red-emitting pyridinium styryl dyes called "channel dyes" have been reported by Kool and coworkers. ${ }^{33}$ In this very interesting report, it is assumed that the insertion 
of a linear styryl dye within the narrow channel of the HaloTag binding pocket results in an increased fluorescence. The probes have however only been used in live imaging of bacteria and the use of cationic pyridinium may cause selectivity conflicts, since it has been reported for similar cationic dyes to accumulate in the mitochondria of eukaryotic cells. ${ }^{34,35}$

In this work, we have set out to develop a series of efficient long wavelength HaloTag fluorogens for targeted livecell imaging. A first series of fluorogen structures was characterized using Bovine Serum Albumine (BSA) as a model protein and the probes were subsequently coupled to a Haloalkane ligand in order to selectively react with HaloTag. The resulting targeted probes were studied in vitro, and then applied to biological imaging in live cells transfected with HaloTag fusion proteins.

\section{Results and discussion}

Probe design and interaction with BSA
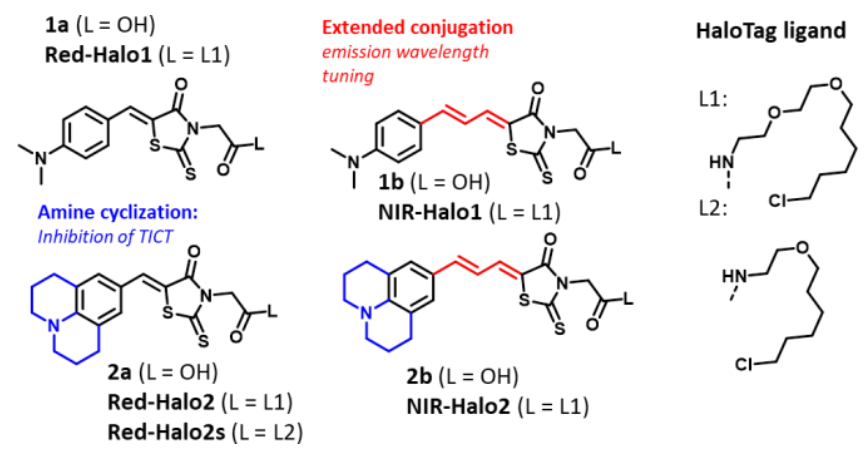

Figure 1. Structures of the fluorogenic protein probes for BSA and Halotag

To achieve fluorogenicity, the probes were rationally designed as push-pull molecular rotors with a dialkylaminobenzene electron-donating group and a rhodanine acceptor group (Figure 1). Two different lengths of $\pi$-conjugation were used to achieve red and NIR emission respectively. In addition to the usual dimethylaminobenzene donor, julolidine derivatives were also synthesized. The cyclization of the donating amine is expected to inhibit the formation of a twisted intramolecular charge transfer (TICT) state that is known to induce non radiative deactivation. ${ }^{36}$ Rhodanine has been chosen since it is neutral, thus preventing non-specific electrostatic interactions, and the carboxylic acid function allows facile further conjugation to a selective protein ligand. Very close derivatives of $\mathbf{1 a}$ and $\mathbf{1} \mathbf{b}$ have previously been reported and display solvatofluorochromic and viscosity-sensitive emissions. ${ }^{35,37}$ The rhodanine benzylidene conjugates also resemble the structure of the GFP chromophore and a similar scaffold can be found, for instance, on previously reported protein or RNA aptamers fluorogens, which makes it overall promising for our purposes. ${ }^{18,38,39}$ The probes were obtained in a straightforward synthesis, using the Knoevenagel condensation of rhodanine-3-acetic acid on the corresponding starting aldehydes, followed by an amide coupling with a halogenoalkane chain (Scheme S1).

\section{Interaction with BSA}

We have first characterized the intermediate probes $\mathbf{1} \mathbf{a}-\mathbf{b}$ and $\mathbf{2} \mathbf{a}-\mathbf{b}$ bearing a carboxylic acid function using bovine serum albumin (BSA). BSA is a serum transport protein that contains several sites able to bind a wide variety of organic and inorganic species. ${ }^{40-42}$ In particular, it has been reported to bind triphenylamine derivatives of our compounds. ${ }^{14}$ As such, it is a good generic model to easily and rapidly assess the fluorogenic character of our probes in a protein environment. The optical properties of probes $\mathbf{1} \mathbf{a}-\mathbf{b}$ and $\mathbf{2} \mathbf{a}-\mathbf{b}$ were thus characterized in presence of BSA (Table 1 \& Figure 2). The fluorescence of the probes is almost negligible in water but, owing to their dipolar flexible structures, they became highly emissive in presence of BSA with large enhancement of the fluorescence intensity by up to 280 -fold (Figure 2B). Fluorimetric titrations of the probes with BSA can be fitted with a one-site binding model and the calculated dissociation constants $\mathrm{K}_{\mathrm{D}}$ are in the micromolar range (Figure S1). This shows that the fluorogenicity originates from a binding equilibrium with albumin with a good affinity leading to hydrophobic interactions and motion restrictions (Figure S1).

Table 1. Optical properties of compounds $1 a-b-2 a-b$ in presence of BSA

\begin{tabular}{|c|c|c|c|c|c|c|}
\hline Molecule & $\lambda$ abs & $\varepsilon\left(\mathrm{M}^{-1} \mathrm{~cm}^{-1}\right)$ & $\lambda e m$ & $\Delta \lambda(\mathrm{nm})$ & $\phi_{\mathrm{F}}$ & $\varepsilon \cdot \phi_{\mathrm{F}}$ \\
\hline 1a & 482 & 45000 & 563 & 77 & 0.034 & 1775 \\
\hline 2a & 516 & 58300 & 590 & 71 & 0.36 & 21000 \\
\hline 1b & 522 & 55600 & 650 & 122 & 0.029 & 1612 \\
\hline 2b & 568 & 26300 & 672 & 104 & 0.081 & 2130 \\
\hline
\end{tabular}


We find as expected a red emission for the benzylidene compounds and a NIR emission for the compounds with extended conjugation (Figure 2A). The cyclization of the donating amino group with a julolidine is accompanied by a red-shift $(20-40 \mathrm{~nm})$ of the absorption and emission wavelengths, in agreement with the stronger donating character of the julolidine, ${ }^{43}$ and by a large increase of the fluorescence quantum yield, thanks to the inhibition of the TICT state formation. ${ }^{36}$ The improvement of the quantum yield results in a much larger fluorescence enhancement in the presence of proteins (26-fold and 281-fold enhancement for 1a and 2a respectively, Figure $2 \mathrm{~B})$. The extension of the conjugation decreases the fluorescence quantum yield, as is often the case for redshifted fluorophores due to the increased rotational freedom and lower energy difference between the ground and excited states. Cyclization of the electron donating amine in the extended structures results in similar increase of the quantum yield and red-shift of the emission wavelength between $\mathbf{1} \mathbf{b}$ and $\mathbf{2} \mathbf{b}$. Overall, compound $\mathbf{2} \mathbf{a}$ is thus the most promising probes with a large fluorescence enhancement and an excellent brightness of $21000 \mathrm{M}^{-1} \mathrm{~cm}^{-1}$, on par with that of common red-emitting fluorescent proteins. ${ }^{44}$ Despite its lower quantum yield, 4 a remains a very interesting fluorogen, considering its NIR emission centered on $672 \mathrm{~nm}$, with a good brightness and a 79-fold fluorescence enhancement in BSA.
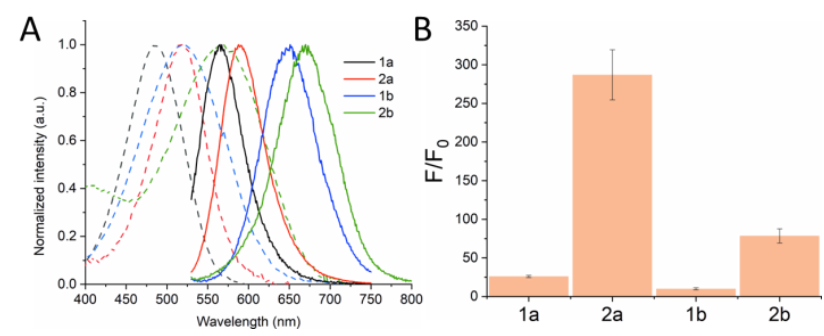

Figure 2. (A) Normalized absorption (dashed lines) and fluorescence emission (solid lines) spectra of compounds $1 \mathrm{a}-4 \mathrm{a}$ in presence of 25 eq of BSA. [dye] $=1 \mu \mathrm{M}$ in $\mathrm{pH} 7.4 \mathrm{PBS}(10$

\section{Interaction with HaloTag in vitro}

BSA remains an unselective protein model that allowed us to identify and characterize a series of putative protein fluorogens. To take advantage of the fluorogenic character and long-wavelength emission in fluorescence imaging, we have next conjugated them to a haloalkane linker in order to target HaloTag fusion proteins.
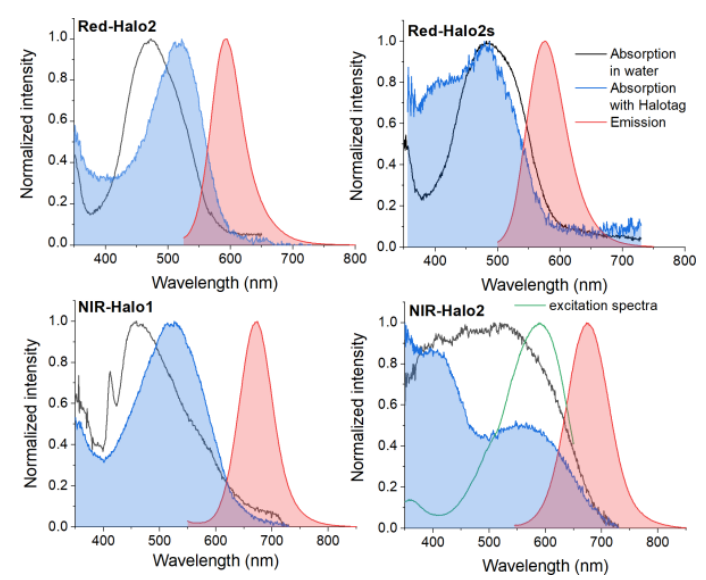

Figure 3. Spectral properties of the fluorogenic HaloTag dyes in water and after reaction with HaloTag. Normalized absorption spectra in water (grey), normalized absorption (blue) and emission (red) spectra in presence of HaloTag. For NIR-Halo2 is also displayed the excitation spectrum in green. [dye] $=1 \mu \mathrm{M},[$ HaloTag] $=1.3 \mu \mathrm{M}$.

The fluorogens were first couped to the standard Halotag ligand reported in the literature to afford the Red-Halo and NIR-Halo compounds (Figure 1). Previous reports have shown that a shorter HaloTag ligand may increase the fluorogenicity through hydrophobic and cation- $\pi$ aromatic interactions or increased motion restriction and we have thus synthesized an analog of Red-Halo2 coupled to a shorter ligand chain with one ethylene glycol unit less: Red-Halo2s (Figure 1). ${ }^{29,33,45}$ We first assessed their optical properties in vitro using a standard GST-HaloTag (GSTHT) protein (Figure 3 and Table S1). Due to the addition of a lipophilic ligand, the HaloTag probes are less soluble in aqueous medium than their free acid counterpart with broad and blue-shifted absorption bands in water showing signs of aggregation (Figure 3). In the presence of HaloTag, the lower-energy absorption bands are similar to those measured in BSA, which results in a red-shift of 50 to $70 \mathrm{~nm}$ in the case of Red-Halo2 and NIR-Halo1 compared to the absorption in water. The emissive properties are also satisfyingly similar, with negligible fluorescence intensities in water and large enhancements of the red and NIR emissions upon reaction with the GST-HT protein (Figure 4A). The fluorescence of $\mathbf{2 a}$ was also measured in presence of GST-HT as a negative control and it displays 
no enhancement of the fluorescence, proving that the fluorogenicity results from a specific reaction between the probes and their target HaloTag.

By following the evolution in time of the fluorescence intensities of our probes upon reaction with HaloTag, we were able to assess the relative reaction kinetics as well as to measure the fluorescence enhancement factors of each compounds (i.e. the ratio between the fluorescence intensity upon complete reaction with HaloTag and the initial fluorescence intensity) (Figure 4). In agreement with the design rationale, starting from the Red-Halo1 structure, the cyclization of the amine elicited a net improvement of the emissive properties, with a fluorescence quantum yield of $17 \%$ and a fluorescence enhancement of 156 for Red-Halo2 bound to HaloTag. The photophysical properties of Red-Halo1 were thus not studied in further details. The shorter HaloTag ligand of RedHalo2s affords a slightly lower enhancement factor of 110, but with a higher fluorescence quantum yield (Table S1). The binding is however associated with a drop in absorptivity that results in a fluorescence brightness about 2.6-fold lower than that of Red-Halo2. This hypochromism, associated with a blue-shift of the absorption band, and with the presence of a shoulder peak around $400 \mathrm{~nm}$, suggests that the insertion of the fluorophore unit within the HaloTag binding pocket induces structural constraints that partially break the electronic conjugation. The speed of the reaction of Red-Halo2s with HaloTag is also the lowest of all the probes (Figure 4B). The HaloTag ligand has been designed to fit the protein binding pocket and, presumably, the presence of bulky groups at the end of a shortened ligand sterically hinders the reaction. Overall, the use of the well-documented standard HaloTag ligand seems preferable with our structures since it results in higher fluorescence brightness and faster reaction.
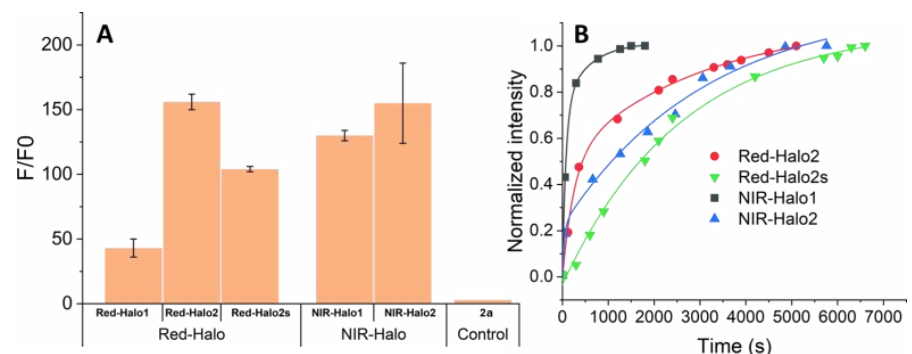

Figure 4. (A) Fluroescence enhancement $F / F_{0}$ of the probes upon reaction with GST-HT. Intermediate 2 was also studied as a negative control (B) Time-course measurement of the normalized integrated fluorescence intensity upon addition of GST-HT $(T=296 \mathrm{~K})$. Trend lines have been added only as a visual guide. [dye] $=1 \mu \mathrm{M}$, [ Halotag] $=1.3 \mu \mathrm{M}$.

In the NIR-Halo series, the dimethylamino compound NIR-Halo1 displays a similar fluorescence enhancement and a higher brightness than its julolidine counterpart, which contradicts the rational design and the properties observed in BSA for the untargeted analogs $\mathbf{1} \mathbf{b}$ and $\mathbf{2} \mathbf{b}$. The absorption spectra of NIR-Halo2 shows, in addition to the lower energy absorption band centered on $565 \mathrm{~nm}$, a main absorption band centered on $408 \mathrm{~nm}$. This higher energy band does not contribute to the fluorescence emission according to the excitation spectra (Figure 3). Since we do not observe a decrease of fluorescence over time (Figure 4B), this form is not the result of degradation and it is more likely that the reaction with HaloTag produces two conformations, including one where NIR-Halo2 is forced into a lesser conjugated, non-fluorescent form. This results in a low brightness and the high fluorescence enhancement factor recorded for NIR-Halo2 is only due to a very low initial intensity $F_{0}$. On the other hand, NIRHalo1 displays a quantum yield of $5.3 \%$ and a brightness that is very satisfactory for a NIR-emitting compound.

Overall, considering brightness and contrast, Red-Halo2 and NIR-Halo1 are very promising fluorogenic HaloTag probes. NIR-Halo1 reacts with HaloTag within 15 minutes, while the reaction with Red-Halo2 is essentially complete after 60 minutes (Figure 3B).

\section{Application to live cell imaging}

Red-Halo2 and NIR-Halo1 were applied in live cell imaging using transfected Hela or HEK-293T cells expressing either HaloTag fused to a triple repeat of a nuclear localization sequence (PKKKRKV) ${ }^{46}$ Halo-NLS(3X) or HaloTag fused to the lifeact peptide Halo-Lifeact for actin imaging. ${ }^{47}$ Cells were incubated with $0.5 \mu \mathrm{M}$ of dye for 30 to 60 minutes and then imaged directly under a confocal microscope without performing washing steps or changing the medium. For both probes and in both cell lines, we observed a selective staining of the target structures (Figure 5, Figure S2). Although the NLS peptide is expected to localize in the nucleoplasm, ${ }^{48}$ the Halo-NLS(3X) fusion protein shows a larger accumulation in the nucleoli, with a very bright signal compared to the nucleoplasm. This can be advantageously used to image the nucleus while simultaneously tracking the dynamics of nucleoli in live cells. 

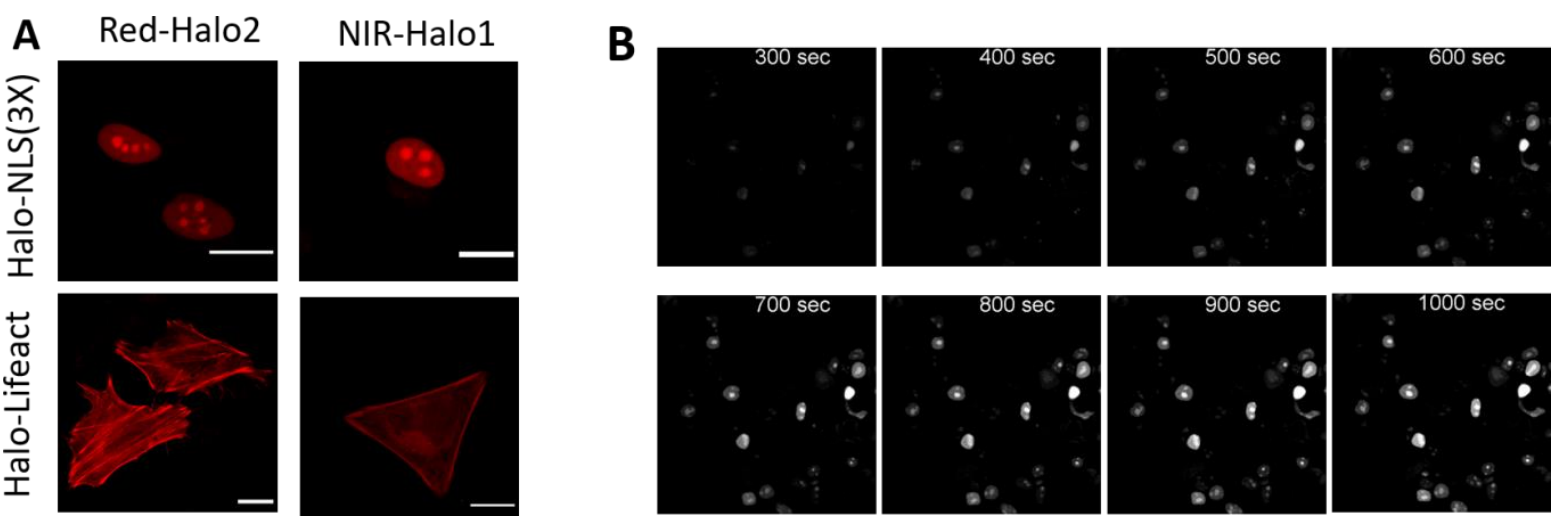

Figure 5. Wash-free live confocal microscopy imaging of HEK-293T cells expressing either the Halo-NLS(3X) or the Halo-lifeact proteins and incubated with compound Red-Halo2 or NIR-Halo1. [dye] $=0.5 \mu \mathrm{M}$, incubation $30-60$ minutes. $\lambda$ exc $=514 \mathrm{~nm}$, collection: $520-790 \mathrm{~nm}$. Scale bar incubated
$=20 \mu \mathrm{m}$.

A time-course measurement of the fluorescence of HEK-293T cells transfected with Halo-NLS(3X) shows that the cell permeation and reaction with HaloTag is complete after ca. 15 minutes (Figure 5B). The faster reaction rate than that observed in cuvette can be explained by the higher temperature and/or the different stoichiometry. Quantitative comparison between the two probes is difficult since the intensity strongly depends on the expression levels of the fusion protein, even between different cells within the same sample (see also Figure S3 for wider field of view images). However, both probes yield bright and contrasted images in agreement with the high fluorescence enhancements recorded in vitro. A faint non-specific signal can nonetheless be recorded in what appears to be the endoplasmic reticulum (ER), a localization that is consistent with previous observations made for similar untargeted structures. ${ }^{35}$ This signal can however be easily discriminated from the brighter specific emission of the probes bound to HaloTag and it does not hamper targeted imaging even in wash-free conditions. It could however be useful in future developments to perform further structure optimization to minimize the unspecific signal, especially to image low-abundant proteins.

\section{Conclusion}

In conclusion, we have developed a series of protein probes displaying bright emissions in the red and NIR range and high fluorogenicity in the presence of BSA. The fluorogens were then coupled to a Halogenoalkane ligand and successfully used for the fluorogenic targeting of HaloTag fusion proteins, albeit with a loss of brightness compared to BSA. The targeted probes are compatible with live cell imaging and were successfully applied to the wash-free imaging of nucleus and actin. The simple push-pull structures of our compounds provide a solid basis for further structure optimization and variations. Modifications of the electron-donor or acceptor moieties may be explored in future developments to fine-tune the photophysical properties, enhance the signal-to-noise ratio or improve cell permeation and labeling kinetics. The comparison between BSA and HaloTag shows that the protein matrix influences the emissive properties but the main characteristics and in particular the high fluorogenicity are conserved in both proteins. By changing the targeting ligand it should thus be possible to use our fluorogens to target a variety of proteins either for imaging applications or to monitor biomolecular interactions in vitro.

\section{Acknowledgments}

The authors would like to thank Marie-Aude Plamont for her assistance in cell culture and Dr. Arnaud Echard for kindly providing molecular biology reagents. This work was supported by the Agence Nationale de la Recherche (ANR-18-CE44-0006).

\section{Conflicts of interests}

There are no conflicts of interest to declare

\section{References:}

(1) Lavis, L. D.; Raines, R. T. Bright Ideas for Chemical Biology. ACS Chem. Biol. 2008, 3 (3), 142-155.

(2) Li, C.; Tebo, A.; Gautier, A. Fluorogenic Labeling Strategies for Biological Imaging. Int. J. Mol. Sci. 2017, 18 (7), 1473.

(3) Bruchez, M. P. Dark Dyes-Bright Complexes: Fluorogenic Protein Labeling. Curr. Opin. Chem. Biol. 2015, $27,18-23$.

(4) Sun, X.; Zhang, A.; Baker, B.; Sun, L.; Howard, A.; Buswell, J.; Maurel, D.; Masharina, A.; Johnsson, K.; Noren, C. J.; et al. Development of SNAP-Tag Fluorogenic Probes for Wash-Free Fluorescence Imaging. ChemBioChem 2011, 12 (14), 2217-2226.

(5) Hori, Y.; Nakaki, K.; Sato, M.; Mizukami, S.; Kikuchi, K. Development of Protein-Labeling Probes with a Redesigned Fluorogenic Switch Based on Intramolecular Association for No-Wash Live-Cell Imaging. Angew. Chemie - Int. Ed. 
2012, 51 (23), 5611-5614.

(6) Wu, H.; Alexander, S. C.; Jin, S.; Devaraj, N. K. A Bioorthogonal Near-Infrared Fluorogenic Probe for MRNA Detection. J. Am. Chem. Soc. 2016, 138 (36), 11429-11432.

(7) Gruskos, J. J.; Zhang, G.; Buccella, D. Visualizing Compartmentalized Cellular Mg2+ on Demand with Small-Molecule Fluorescent Sensors. J. Am. Chem. Soc. 2016, 138 (44), 14639-14649.

(8) Wieczorek, A.; Werther, P.; Euchner, J.; Wombacher, R. Green- to Far-Red-Emitting Fluorogenic Tetrazine ProbesSynthetic Access and No-Wash Protein Imaging inside Living Cells. Chem. Sci. 2017, 8 (2), 1506-1510.

(9) Wang, L.; Tran, M.; D’Este, E.; Roberti, J.; Koch, B.; Xue, L.; Johnsson, K. A General Strategy to Develop Cell Permeable and Fluorogenic Probes for Multicolour Nanoscopy. Nat. Chem. 2020, 12 (2), 165-172.

(10) Grimm, J. B.; Muthusamy, A. K.; Liang, Y.; Brown, T. A.; Lemon, W. C.; Patel, R.; Lu, R.; Macklin, J. J.; Keller, P. J.; Ji, N.; et al. A General Method to Fine-Tune Fluorophores for Live-Cell and in Vivo Imaging. Nat. Methods 2017, 14 (10), 987-994.

(11) Klymchenko, A. S. Solvatochromic and Fluorogenic Dyes as Environment-Sensitive Probes: Design and Biological Applications. Acc. Chem. Res. 2017, 50 (2), 366-375.

(12) Su, D.; Teoh, C. L.; Wang, L.; Liu, X.; Chang, Y.-T. Motion-Induced Change in Emission (MICE) for Developing Fluorescent Probes. Chem. Soc. Rev. 2017, 46 (16), 4833-4844.

(13) Goh, W. L.; Lee, M. Y.; Joseph, T. L.; Quah, S. T.; Brown, C. J.; Verma, C.; Brenner, S.; Ghadessy, F. J.; Teo, Y. N. Molecular Rotors As Conditionally Fluorescent Labels for Rapid Detection of Biomolecular Interactions. J. Am. Chem. Soc. 2014, 136 (17), 6159-6162.

(14) Dumat, B.; Bordeau, G.; Aranda, A. I.; Mahuteau-Betzer, F.; Harfouch, Y. El; Metgé, G.; Charra, F.; FioriniDebuisschert, C.; Teulade-Fichou, M.-P. Vinyl-Triphenylamine Dyes, a New Family of Switchable Fluorescent Probes for Targeted Two-Photon Cellular Imaging: From DNA to Protein Labeling. Org. Biomol. Chem. 2012, 10 (30), 6054.

(15) Dumat, B.; Bordeau, G.; Faurel-Paul, E.; Mahuteau-betzer, F.; Saettel, N.; Metge, G.; Fiorini-debuisschert, C.; Charra, F.; Teulade-Fichou, M.-P.; Charrab, F.; et al. DNA Switches on the Two-Photon Efficiency of an Ultrabright Triphenylamine Fluorescent Probe Specific of AT Regions. J. Am. Chem. Soc. 2013, 135 (34), 12697-12706.

(16) Goh, W. L.; Lee, M. Y.; Lim, T. X.; Chua, J. S.; Brenner, S.; Ghadessy, F. J.; Teo, Y. N. A Novel Molecular Rotor Facilitates Detection of P53-DNA Interactions Using the Fluorescent Intercalator Displacement Assay. Sci. Rep. 2018, 8 (1), 1-13.

(17) Rosania, G. R.; Lee, J. W.; Ding, L.; Yoon, H.-S.; Chang, Y.-T. Combinatorial Approach to Organelle-Targeted Fluorescent Library Based on the Styryl Scaffold. J. Am. Chem. Soc. 2003, 125 (5), 1130-1131.

(18) Plamont, M.-A.; Billon-Denis, E.; Maurin, S.; Gauron, C.; Pimenta, F. M.; Specht, C. G.; Shi, J.; Quérard, J.; Pan, B.; Rossignol, J.; et al. Small Fluorescence-Activating and Absorption-Shifting Tag for Tunable Protein Imaging in Vivo. Proc. Natl. Acad. Sci. 2016, 113 (3), 497-502.

(19) Karpenko, I. A.; Bonnet, D.; Niko, Y.; Klymchenko, A. S.; Yakubovskyi, V. P.; Gerasov, A. O.; Kovtun, Y. P. Push-Pull Dioxaborine as Fluorescent Molecular Rotor: Far-Red Fluorogenic Probe for Ligand-Receptor Interactions. J. Mater. Chem. C 2016, 4 (14), 3002-3009.

(20) Xue, L.; Karpenko, I. A.; Hiblot, J.; Johnsson, K. Imaging and Manipulating Proteins in Live Cells through Covalent Labeling. Nat. Chem. Biol. 2015, 11 (12), 917-923.

(21) Lukinavičius, G.; Johnsson, K. Switchable Fluorophores for Protein Labeling in Living Cells. Curr. Opin. Chem. Biol. 2011, 15 (6), 768-774.

(22) Keppler, A.; Gendreizig, S.; Gronemeyer, T.; Pick, H.; Vogel, H.; Johnsson, K. A General Method for the Covalent Labeling of Fusion Proteins with Small Molecules in Vivo. Nat. Biotechnol. 2003, 21 (1), 86-89.

(23) Los, G. V.; Encell, L. P.; McDougall, M. G.; Hartzell, D. D.; Karassina, N.; Zimprich, C.; Wood, M. G.; Learish, R.; Ohana, R. F.; Urh, M.; et al. HaloTag: A Novel Protein Labeling Technology for Cell Imaging and Protein Analysis. ACS Chem. Biol. 2008, 3 (6), 373-382.

(24) Mueller, V.; Luo, Z.-G.; Johnsson, K.; Lukinavičius, G.; Olivier, N.; Eggeling, C.; Umezawa, K.; Plass, T.; Schultz, C.; Reymond, L.; et al. A Near-Infrared Fluorophore for Live-Cell Super-Resolution Microscopy of Cellular Proteins. Nat. Chem. 2013, 5 (2), 132-139.

(25) Tomat, E.; Nolan, E. M.; Jaworski, J.; Lippard, S. J. Organelle-Specific Zinc Detection Using Zinpyr-Labeled Fusion Proteins in Live Cells. J. Am. Chem. Soc. 2008, 130 (47), 15776-15777.

(26) Yang, G.; de Castro Reis, F.; Sundukova, M.; Pimpinella, S.; Asaro, A.; Castaldi, L.; Batti, L.; Bilbao, D.; Reymond, L.; Johnsson, K.; et al. Genetic Targeting of Chemical Indicators in Vivo. Nat. Methods 2015, 12 (2), 137-139.

(27) Leng, S.; Qiao, Q.; Miao, L.; Deng, W.; Cui, J.; Xu, Z. A Wash-Free SNAP-Tag Fluorogenic Probe Based on the Additive Effects of Quencher Release and Environmental Sensitivity. Chem. Commun. 2017, 53 (48), 6448-6451.

(28) Yu, W. T.; Wu, T. W.; Huang, C. L.; Chen, I. C.; Tan, K. T. Protein Sensing in Living Cells by Molecular Rotor-Based Fluorescence-Switchable Chemical Probes. Chem. Sci. 2016, 7 (1), 301-307.

(29) Liu, Y.; Miao, K.; Dunham, N. P.; Liu, H.; Fares, M.; Boal, A. K.; Li, X.; Zhang, X. The Cation- $\pi$ Interaction Enables a Halo-Tag Fluorogenic Probe for Fast No-Wash Live Cell Imaging and Gel-Free Protein Quantification. Biochemistry 
2017, 56 (11), 1585-1595.

(30) Jiang, X.; Boal, A. K.; Liu, Y.; Fares, M.; Dunham, N. P.; Gao, Z.; Zhang, X.; Bollinger, S. S.; Miao, K. AgHalo: A Facile Fluorogenic Sensor to Detect Drug-Induced Proteome Stress. Angew. Chemie Int. Ed. 2017, 56 (30), 8672-8676.

(31) Zhang, X.; Fares, M.; Zhai, Y.; Liu, Y.; Miao, K.; Li, Y.; Gao, Z. A Molecular Rotor-Based Halo-Tag Ligand Enables a Fluorogenic Proteome Stress Sensor to Detect Protein Misfolding in Mildly Stressed Proteome. Bioconjug. Chem. 2017, 29 (1), 215-224.

(32) Jung, K. H.; Fares, M.; Grainger, L. S.; Wolstenholme, C. H.; Hou, A.; Liu, Y.; Zhang, X. A SNAP-Tag Fluorogenic Probe Mimicking the Chromophore of the Red Fluorescent Protein Kaede. Org. Biomol. Chem. 2019, 17 (7), 1906-1915.

(33) Clark, S. A.; Singh, V.; Vega Mendoza, D.; Margolin, W.; Kool, E. T. Light-Up “Channel Dyes" for Haloalkane-Based Protein Labeling in Vitro and in Bacterial Cells. Bioconjug. Chem. 2016, 27 (12), 2839-2843.

(34) Chennoufi, R.; Bougherara, H.; Gagey-Eilstein, N.; Dumat, B.; Henry, E.; Subra, F.; Mahuteau-Betzer, F.; Tauc, P.; Teulade-Fichou, M.-P.; Deprez, E. Differential Behaviour of Cationic Triphenylamine Derivatives in Fixed and Living Cells: Triggering and Imaging Cell Death. Chem. Commun. 2015, 51 (80), 14881-14884.

(35) Li, C.; Plamont, M.; Aujard, I.; Le Saux, T.; Jullien, L.; Gautier, A. Design and Characterization of Red Fluorogenic Push-Pull Chromophores Holding Great Potential for Bioimaging and Biosensing. Org. Biomol. Chem. 2016, 14 (39), 9253-9261.

(36) Grabowski, Z. R.; Rotkiewicz, K.; Rettig, W. Structural Changes Accompanying Intramolecular Electron Transfer: Focus on Twisted Intramolecular Charge-Transfer States and Structures. Chem. Rev. 2003, 103 (10), 3899-4031.

(37) Rekaï, E. D.; Baudin, J. B.; Jullien, L.; Ledoux, I.; Zyss, J.; Blanchard-Desce, M. A Hyperpolar, Multichromophoric Cyclodextrin Derivative: Synthesis, and Linear and Nonlinear Optical Properties. Chem. - A Eur. J. 2001, 7 (20), 4395-4402.

(38) Pellerano, M.; Naud-Martin, D.; Peyressatre, M.; Prével, C.; Teulade-Fichou, M.-P.; Morris, M.; Mahuteau-Betzer, F. TP-2Rho Is a Sensitive Solvatochromic Red-Shifted Probe for Monitoring the Interactions between CDK4 and Cyclin D. ChemBioChem 2016, 17 (8), 737-744.

(39) You, M.; Jaffrey, S. R. Structure and Mechanism of RNA Mimics of Green Fluorescent Protein. Annu. Rev. Biophys. 2015, 44 (1), 187-206.

(40) Dockal, M.; Carter, D. C.; Rüker, F. The Three Recombinant Domains of Human Serum Albumin. Structural Characterization and Ligand Binding Properties. J. Biol. Chem. 1999, 274 (41), 29303-29310.

(41) Jisha, V. S.; Arun, K. T.; Hariharan, M.; Ramaiah, D. Site-Selective Binding and Dual Mode Recognition of Serum Albumin by a Squaraine Dye. J. Am. Chem. Soc. 2006, 128 (18), 6024-6025.

(42) Samanta, S.; Halder, S.; Das, G. Twisted-Intramolecular-Charge-Transfer-Based Turn-On Fluorogenic Nanoprobe for Real-Time Detection of Serum Albumin in Physiological Conditions. Anal. Chem. 2018, 90 (12), 7561-7568.

(43) Kwon, O.; Barlow, S.; Odom, S. A.; Beverina, L.; Thompson, N. J.; Zojer, E.; Brédas, J. L.; Marder, S. R. Aromatic Amines: A Comparison of Electron-Donor Strengths. J. Phys. Chem. A 2005, 109 (41), 9346-9352.

(44) Shaner, N. C.; Steinbach, P. A.; Tsien, R. Y. A Guide to Choosing Fluorescent Proteins. Nat. Methods 2005, 2 (12), 905-909.

(45) Kang, M.-G.; Lee, H.; Kim, B. H.; Dunbayev, Y.; Seo, J. K.; Lee, C.; Rhee, H.-W. Structure-Guided Synthesis of a Protein-Based Fluorescent Sensor for Alkyl Halides. Chem. Commun. 2017, 53 (66), 9226-9229.

(46) Kalderon, D.; Roberts, B. L.; Richardson, W. D.; Smith, A. E. A Short Amino Acid Sequence Able to Specify Nuclear Location. Cell 1984, 39 (3 PART 2), 499-509.

(47) Riedl, J.; Crevenna, A. H.; Kessenbrock, K.; Yu, J. H.; Neukirchen, D.; Bista, M.; Bradke, F.; Jenne, D.; Holak, T. A.; Werb, Z.; et al. Lifeact: A Versatile Marker to Visualize F-Actin. Nat. Methods 2008, 5 (7), 605-607.

(48) Martin, R. M.; Leonhardt, H.; Cardoso, M. C. DNA Labeling in Living Cells. Cytometry. A 2005, 67 (1), 45-52. 


\section{Fluorogenic Protein Probes with Red or Near-Infrared Emission for Genetically Targeted Live-Cell Imaging}

Sylvestre P. J. T. Bachollet, ${ }^{a}$ Cyril Addi, ${ }^{b}$ Jean-Maurice Mallet ${ }^{a}$ and Blaise Dumat*a

a Laboratoire des biomolécules, LBM, Département de chimie, École normale supérieure, PSL University, Sorbonne Université, CNRS, 75005 Paris, France.

${ }^{\mathrm{b}}$ Membrane Traffic and Cell Division Lab, Cell Biology and Infection Department, Institut Pasteur, CNRS UMR3691, Sorbonne Université, 75005 Paris.

*E-mail: blaise.dumat@ens.psl.eu

\section{Supplementary material}

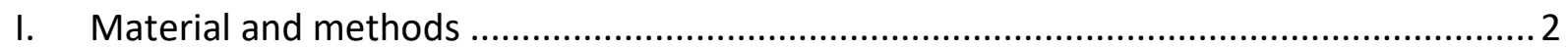

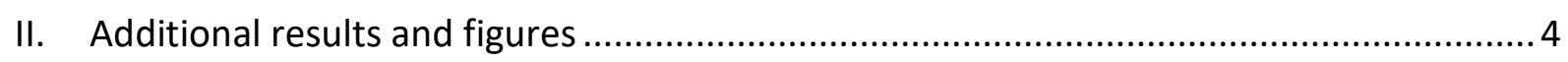

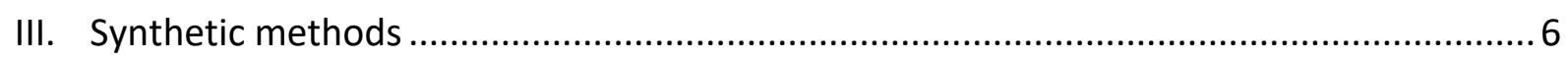

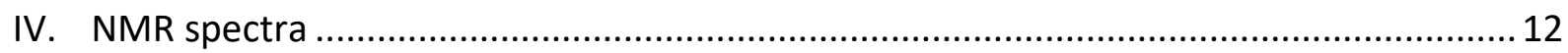

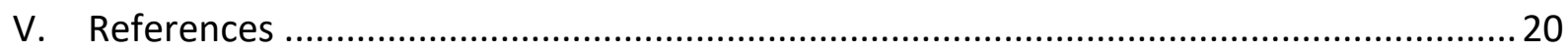




\section{Material and methods}

Materials. Chemical reagents and solvents were purchased from Sigma-Aldrich or TCl and were used as received. Purified GST-Halotag protein (product \#G4491) was purchased from Promega Corp. (Madison, Wi, USA) at a concentration of $2.55-2.63 \mathrm{mg} / \mathrm{ml}$ depending on the lot number. HEK-293T (CRL-3216) and Hela (CCL-2) cells were obtained from the ATCC.

Chemical analysis. ${ }^{1} \mathrm{H}$ and ${ }^{13} \mathrm{C}$ NMR spectra were recorded on a Bruker Advance $300 \mathrm{MHz}$ spectrometer. All chemical shifts $(\delta)$ for ${ }^{1} \mathrm{H}$ and ${ }^{13} \mathrm{C}$ NMR spectra are reported in parts per million (ppm) relative to the internal residual solvent signals. The abbreviations used are: singulet $(s)$, doublet $(d)$, doublet of doublet $(d d)$, triplet $(t)$, doublet of triplet (dt), multiplet (m) and coupling constants are reported in hertz (Hz). HPLC: analytical HPLC was performed on an Agilent 1200 series equipped with a quaternary pump using a Proto 200 C18 from Higgins Analytical Inc (particles size $3 \mu \mathrm{m}, 100 \times 4.6 \mathrm{~mm}$ column). Preparative HPLC was performed on an Agilent 1260 Infinity using a Nucleodur C18 HTech column from MachereyNagel Inc. (particles size $5 \mu \mathrm{m}, 250 \times 16 \mathrm{~mm}$ column) with a gradient of $30 \mathrm{~min}$ from $50 \%$ to $100 \%$ acetonitrile $(0,1 \%$ TFA) / water $(0,1 \%$ TFA) at $220 \mathrm{~nm}$. ESI-MS experiments were carried out using a LTQ-Orbitrap XL from Thermo Scientific (Thermo Fisher Scientific, Courtaboeuf, France) and operated in positive or negative ionization mode, with a spray voltage at $3.6 \mathrm{kV}$. Applied voltages were 40 and $100 \mathrm{~V}$ for the ion transfer capillary and the tube lens, respectively. The ion transfer capillary was held at $275^{\circ} \mathrm{C}$. Detection was achieved in the Orbitrap with a resolution set to 100,000 (at $\mathrm{m} / \mathrm{z} 400$ ) and a $\mathrm{m} / \mathrm{z}$ range between 200-2000 in profile mode. Spectrum was analyzed using the acquisition software XCalibur 2.1 (Thermo Fisher Scientific, Courtaboeuf, France). The automatic gain control (AGC) allowed accumulation of up to 2.105 ions for FTMS scans, Maximum injection time was set to $300 \mathrm{~ms}$ and $1 \mu$ scan was acquired. $10 \mu \mathrm{L}$ was injected using a Thermo Finnigan Surveyor HPLC system (Thermo Fisher Scientific, Courtaboeuf, France) with a continuous infusion of methanol at $100 \mu \mathrm{L}$.min-1. Thin layer chromatography (TLC) analysis was run on silica gel (Merck 60F - 254) with visualization at $254 \mathrm{~nm}$.

Absorption and fluorescence spectroscopy. UV spectra were recorded on a Cary 300 spectrophotometer (Agilent technologies, Santa Clara, CA, USA). Scanning was set at 600 $\mathrm{nm} / \mathrm{min}$ with a step of $1 \mathrm{~nm}$. Fluorescence emission spectra were recorded on a Jasco FP8300 spectrofluorometer (Jasco Inc., Easton, MD, USA). Scanning speed was set to 500 $\mathrm{nm} / \mathrm{min}$, excitation and emission slits were set to $5 \mathrm{~nm}$ and the PMT to medium. Measurements were performed in quartz cuvettes ( $1 \mathrm{~cm}$ pathlength, Hellma Analytics).

Interaction with Bovine Serum Albumine (BSA). The fluorogenic dyes were dissolved in DMSO at a stock concentration of $1 \mathrm{mM}$. The titration of the probes by BSA was performed by adding increasing amounts of BSA in the working solution $(1 \mu \mathrm{M}$ probe concentration in $1 \mathrm{~mL}$ of $10 \mathrm{mM}$ phosphate buffer $\mathrm{pH} 7.2$ containing $100 \mathrm{mM}$ of $\mathrm{NaCl}$ ) and recording the fluorescence spectrum. The resulting titration curves were fitted to a one-site binding model using Origin Pro 9 software.

Interaction with HaloTag. The fluorogenic dyes were dissolved in DMSO at a stock concentration of $0.5 \mathrm{mM}$. The interaction of the probes with Halotag was assessed by incubating the dye at $1 \mu \mathrm{M}(0.4 \mu \mathrm{L}$ of stock solution) concentration with $1.3 \mu \mathrm{M}$ (ca. $6 \mu \mathrm{L}$ of commercial stock solution) of protein in a $200 \mu \mathrm{L}$ working volume of pH7.4 Phosphate buffer (10 mM phosphate with $100 \mathrm{mM} \mathrm{NaCl}$ ). The fluorescence spectra were then recorded at 
regular time intervals over the course of the reaction. After complete reaction with Halotag, the absorption spectra of the protein-bound chromophores were also recorded.

Fluorescence quantum yield measurements. Fluorescence quantum yield were calculated by relative measurement using Rhodamine $6 \mathrm{G}$ as reference $\left(\phi_{F}=0.94\right.$ in ethanol) using the reported strategy. ${ }^{1}$ Briefly, the fluorescence of each sample was recorded at three different excitation wavelength as well the absorption spectra. The fluorescence quantum yield was then calculated at each wavelength using equation (1) and averaged.

(1) $\varphi_{f}^{i}=\varphi_{f}^{s} \frac{F^{i}\left(1-10^{-A^{s}}\right) n_{i}^{2}}{F^{s}\left(1-10^{-A^{i}}\right) n_{s}^{2}}$

Where $\phi_{\mathrm{F}}$ is the fluorescence quantum yield, $\mathrm{F}$ the integrated fluorescence intensity, $A$ the absorbance at the excitation wavelength, $\mathrm{n}$ the refractive index of the solvent and the superscript $s$ and $i$ refer to the standard and the sample respectively.

Plasmid construction. To generate the expression plasmid pHaloTag-C1, the HaloTag coding sequence was PCR amplified and digested with Agel and Xhol restriction enzymes. This DNA fragment was used to replace the GFP coding sequence in the vector pEGFP-C1 (Clontech). The pHaloTag-C1 was subsequently digested with Agel and Xbal restriction enzymes to isolate the HaloTag coding sequence and this fragment was used to replace the $\mathrm{mScarlet}$ coding sequence in the pLifeAct-mScarlet-N1 (Plasmid Addgene \#85054) to generate the pLifeAct-HaloTag-N1 expression plasmid. This plasmid encoded a fusion protein that is MGVADLIKKFESISKEEGDPPVATMGSEI...EISGASGLRSRAQASNSAVDGTAGPGSTGSRS, where the LifeAct sequence is underlined and the HaloTag sequence is in bold. In order to generate the pHaloTag-3xNLS expression plasmid, the pHaloTag-C1 was digested with Nhel and Xhol restriction enzymes to isolate the HaloTag coding sequence and this fragment was used to replace the mCherry coding sequence in the pmCherry-3xNLS (Plasmid Addgene \#39319). The resulting plasmid encoded a fusion protein that is MGSEI...EISGASGLRSRADPKKKRKVDPKKKRKVDPKKKRKVGSTGSR, where the 3xNLS sequence is underlined and the HaloTag sequence is in bold.

Confocal microscopy. HEK-293T and Hela cells were grown overnight on 8-well polymer $\mu$ slides from Ibidi (\#1.5 polylmer coverslip, tissue culture treated) at $50 \mathrm{k}$ to $100 \mathrm{k}$ cells/well in $300 \mu \mathrm{L}$ of culture medium (Gibco) supplemented with $10 \%$ fcs. Culture medium was DMEM for HEK-293T cells and MEM (supplemented with sodium pyruvate and non-essential aminoacids) for Hela cells. Cells were then transfected with the desired plasmid using Fugene 6 (Promega Corp.) according to the manufacturer's protocol. After 24 hours, the cells were incubated 30-60 minutes with the dyes and imaged live on a Zeiss LSM710 laser scanning confocal microscope equipped with a Plan apochromat 40X/1.4 NA objective. Images were acquired using Zen 2009 software and then processed using ImageJ. $\lambda_{\text {exc }}=514$ $\mathrm{nm}$, collection: $520-797 \mathrm{~nm}$. 


\section{Additional results and figures}

$$
\underset{\Delta}{\longrightarrow}
$$

(n)

Scheme S1 : General synthetic scheme 


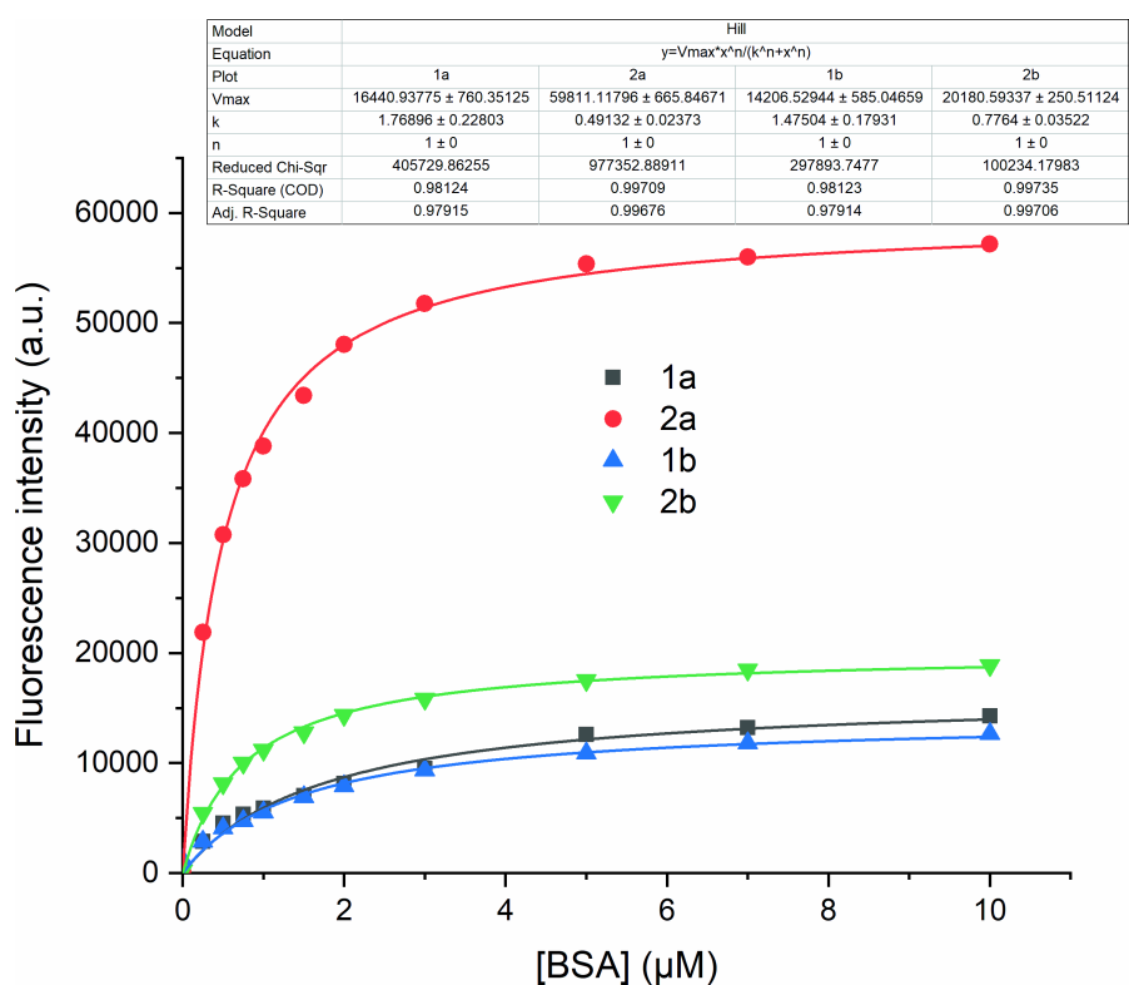

Figure S1. Fluorimetric titration of probes $\mathbf{1} \mathbf{a}-\mathbf{b}$ and $\mathbf{2} \mathbf{a}-\mathbf{b}$ with BSA. Curves were fitted to a one-site binding model. [Dye] $=1 \mu \mathrm{M},[\mathrm{BSA}]=1-10 \mu \mathrm{M}$ in pH7.2 phosphate buffer containing $10 \mathrm{mM}$ Phosphate and $100 \mathrm{mM} \mathrm{NaCl}$

Table S1. Optical properties of the HaloTag fluorogenic probes in the presence of GST-HT. Maximum absorption wavelength $\left(\lambda_{\text {abs }}\right)$, molar absorptivity $(\varepsilon)$, maximum emission wavelength $\left(\lambda_{\mathrm{em}}\right)$, Stokes shift in $\mathrm{nm}(\Delta \lambda)$, fluorescence quantum yield $\left(\phi_{\mathrm{F}}\right)$ and brightness $\left(\varepsilon \cdot \phi_{\mathrm{F}}\right)$.

\begin{tabular}{ccccccc}
\hline Probe & $\boldsymbol{\lambda}_{\text {abs }}(\mathbf{n m})$ & $\boldsymbol{\varepsilon}\left(\mathbf{M}^{-1} \cdot \mathbf{c m}^{-1}\right)$ & $\boldsymbol{\lambda}_{\text {em }}(\mathbf{n m})$ & $\boldsymbol{\Delta} \boldsymbol{\lambda}(\mathbf{n m})$ & $\boldsymbol{\phi}_{\mathrm{F}}$ & $\boldsymbol{\varepsilon} \cdot \boldsymbol{\phi}_{\mathrm{F}}$ \\
\hline Red-Halo1 & $490^{\mathrm{a}}$ & - & 575 & 85 & - & - \\
Red-Halo2 & 515 & 21000 & 592 & 77 & 0.17 & 3600 \\
Red-Halo2s & 487 & 6800 & 578 & 91 & 0.24 & 1632 \\
NIR-Halo1 & 526 & 25800 & 671 & 145 & 0.053 & 1400 \\
NIR-Halo2 & $(408) ; 565$ & 7900 & 681 & 116 & 0.038 & 300 \\
\hline
\end{tabular}

${ }^{\text {a }}$ determined via the excitation spectra.

Note: Due to the formation of several conformations as evidenced by UV-absorption spectroscopy, the fluorescence quantum yields of NIR-Halo2 and Red-Halo2s are merely apparent quantum yields used for comparison purposes.

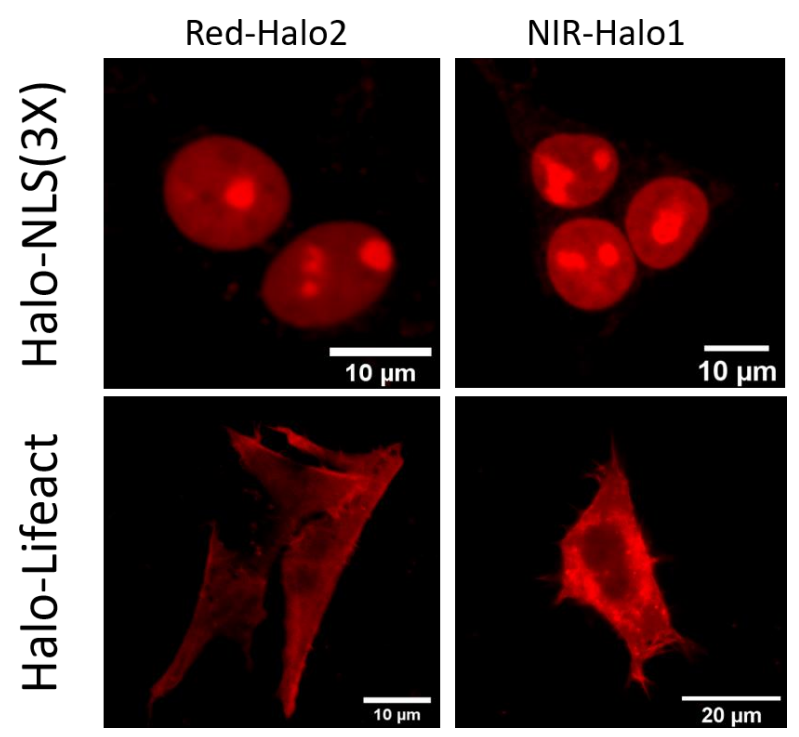



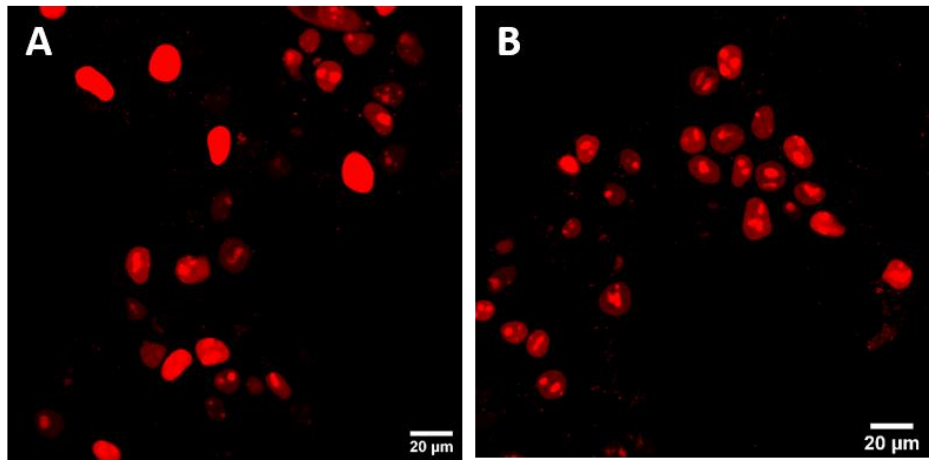

Figure S3. Wash-free live confocal imaging of HEK-293T cells transfected with Halo-NLS(3X) and labeled with $0.5 \mu \mathrm{M}$ of (A) Red-Halo2 and (B) NIRHalo1. [dye] $=0.5 \mu \mathrm{M}$, incubation $30-60$ minutes. $\lambda_{\mathrm{exc}}=514 \mathrm{~nm}$, collection: $520-790 \mathrm{~nm}$. The intensity in some cells is purposely saturated to make visible lesser transfected cells.

\section{Synthetic methods}

Compounds $\mathbf{1} \mathbf{a}^{2}$ and $\mathbf{S \mathbf { 1 } ^ { 3 }}$ were synthetized using previously reported procedures.

(Z)-N-(2-(2-((6-chlorohexyl)oxy)ethoxy)ethyl)-2-(5-(4-(dimethylamino)benzylidene)-4-oxo2-thioxothiazolidin-3-yl)acetamide Red-Halo1
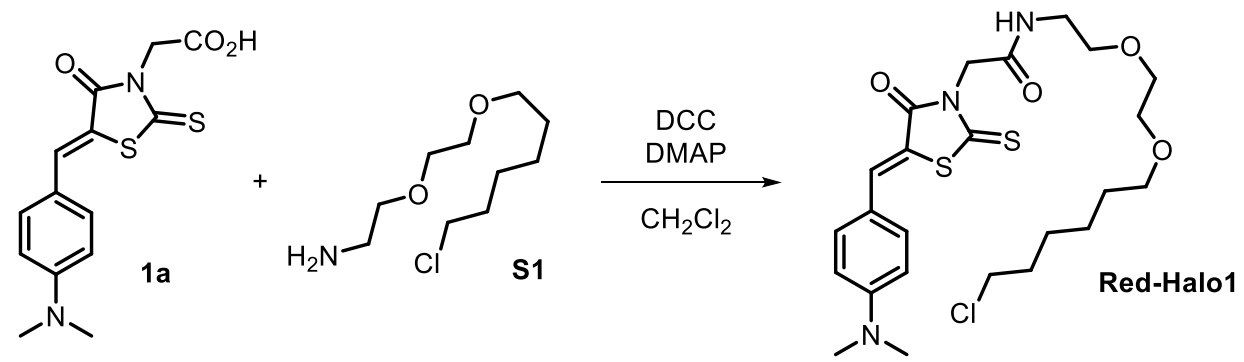

To a stirred suspension of 1a (144 mg, $0.45 \mathrm{mmol}, 1.0 \mathrm{eq}), \mathbf{S 1}(100 \mathrm{mg}, 0.45 \mathrm{mmol}$, $1.0 \mathrm{eq}$ ) and DMAP (55 mg, $0.45 \mathrm{mmol}, 1.0 \mathrm{eq})$ in DCM $(8.5 \mathrm{~mL}$ ) was added DCC (92 mg, 0.45 $\mathrm{mmol}, 1.0 \mathrm{eq}$ ) and the reaction was stirred at room temperature overnight in the dark. The mixture was evaporated to dryness and the crude product was purified by column chromatography (EtOAc:DCM, 0:1 to 1:4). Recrystallization from EtOH afforded Red-Halo1 (93 mg, 45\%) as a red solid. ${ }^{1} \mathbf{H}$ NMR $\left(300 \mathrm{MHz}, \mathrm{CDCl}_{3}\right): 7.67(\mathrm{~s}, 1 \mathrm{H}), 7.37(\mathrm{~d}, \mathrm{~J}=9.0 \mathrm{~Hz}, 2 \mathrm{H}$ ), $6.70(\mathrm{~d}, \mathrm{~J}=9.0 \mathrm{~Hz}, 2 \mathrm{H}), 6.47-6.37(\mathrm{~m}, 1 \mathrm{H}), 4.76(\mathrm{~s}, 2 \mathrm{H}), 3.63-3.41(\mathrm{~m}, 12 \mathrm{H}), 3.06(\mathrm{~s}, 6 \mathrm{H}), 1.81-$ $1.70(\mathrm{~m}, 2 \mathrm{H}), 1.64-1.53(\mathrm{~m}, 2 \mathrm{H}), 1.48-1.32(\mathrm{~m}, 4 \mathrm{H}) .{ }^{13} \mathrm{C} \mathrm{NMR}\left(75 \mathrm{MHz}, \mathrm{CDCl}_{3}\right): \delta 193.3,167.6$, 165.1, 152.0, 135.5, 133.4, 120.8, 115.3, 112.1, 71.4, 70.5, 70.2, 69.7, 46.7, 45.2, 40.1, 39.6, 32.6, 29.5, 26.8, 25.5. HRMS calcd for $\mathrm{C}_{24} \mathrm{H}_{34} \mathrm{ClN}_{3} \mathrm{O}_{4} \mathrm{~S}_{2} \mathrm{~K}$ : 566.1311. Found: 566.1307. HPLC $95 \%$.

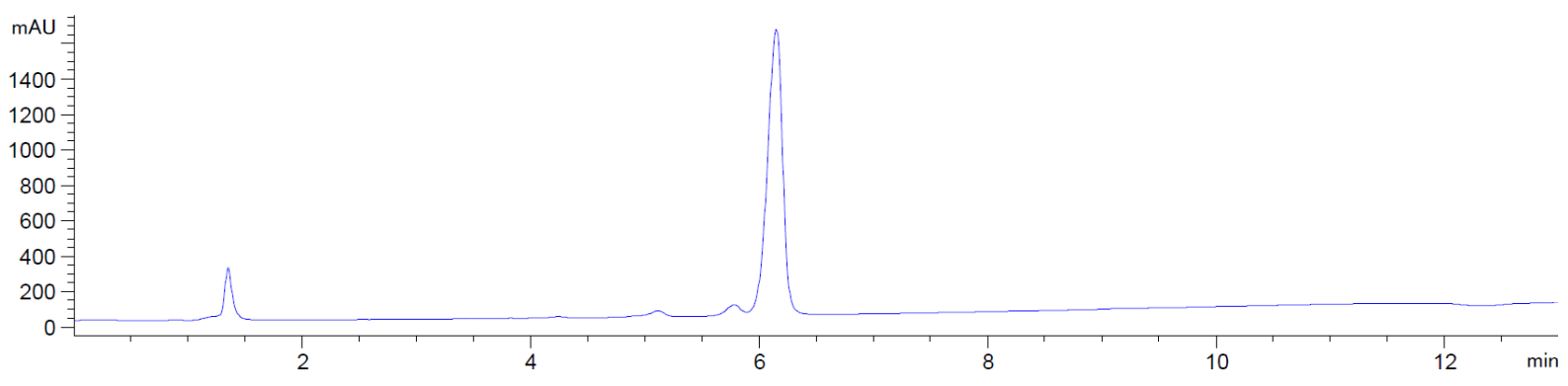




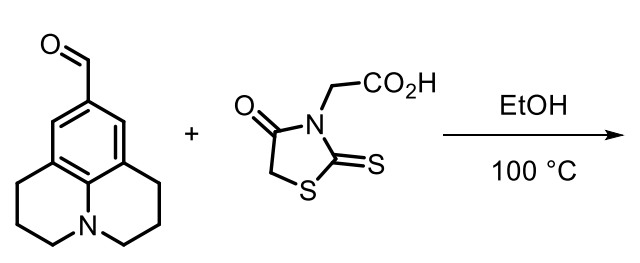<smiles>O=C(O)CN1C(=O)S/C(=C\c2cc3c4c(c2)CCCN4CCC3)C1=O</smiles>

A solution of julolidine (105 mg, $0.52 \mathrm{mmol}, 1.0 \mathrm{eq}$ ) and rhodanine-3-acetic acid (100 $\mathrm{mg}, 0.52 \mathrm{mmol}, 1.0 \mathrm{eq})$ in ethanol $(7.0 \mathrm{~mL})$ was stirred at $100{ }^{\circ} \mathrm{C}$ overnight in the dark. The mixture was filtered and washed with ethanol to give $2 \mathbf{2 a}(143 \mathrm{mg}, 73 \%)$ as a red solid. ${ }^{1} \mathbf{H}$ NMR (300 MHz, DMSO-d $\left.\mathrm{d}_{6}\right)$ : $13.38(\mathrm{~s}, 1 \mathrm{H}), 7.59(\mathrm{~s}, 1 \mathrm{H}), 7.06(\mathrm{~s}, 2 \mathrm{H}), 4.70(\mathrm{~s}, 2 \mathrm{H}), 3.32-3.27(\mathrm{~m}$, $4 \mathrm{H}), 2.76-2.69(\mathrm{~m}, 4 \mathrm{H}), 1.93-1.82(\mathrm{~m}, 4 \mathrm{H}) .{ }^{13} \mathrm{C}$ NMR (75 MHz, DMSO-d $\left.\mathrm{d}_{6}\right): \delta 192.3,167.5$, $166.3,145.9,135.6,130.9,121.3,118.6,111.3,49.4,44.9,27.0,20.6$. HRMS calcd for $\mathrm{C}_{18} \mathrm{H}_{17} \mathrm{~N}_{2} \mathrm{O}_{3} \mathrm{~S}_{2}:$ 373.0686. Found: 373.0685. HPLC 99\%.

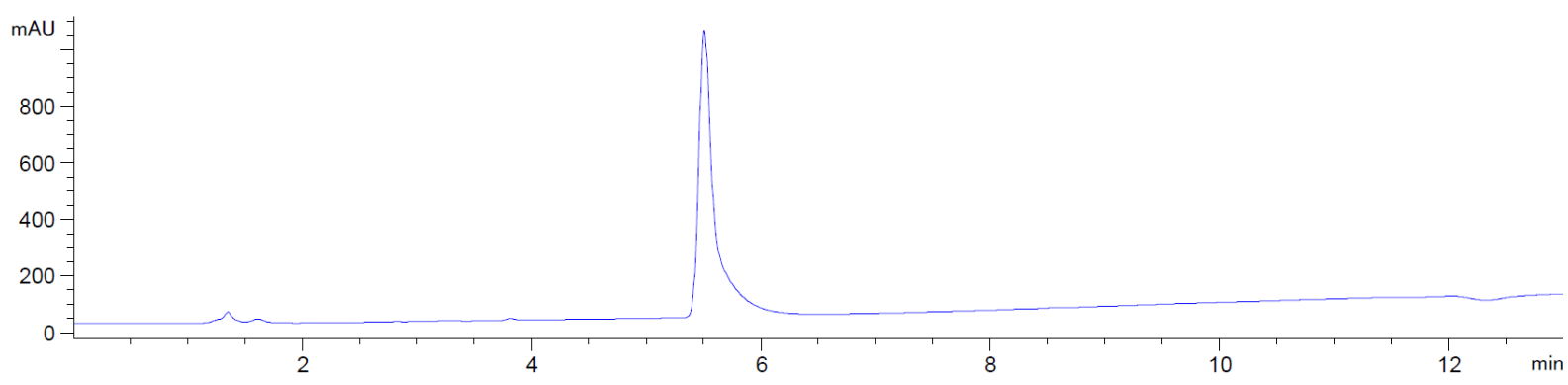

(Z)-N-(2-(2-((6-chlorohexyl)oxy)ethoxy)ethyl)-2-(4-oxo-5-((2,3,6,7-tetrahydro-1H,5Hpyrido[3,2,1-ij]quinolin-9-yl)methylene)-2-thioxothiazolidin-3-yl)acetamide Red-Halo2<smiles>O=C(O)CN1C(=O)/C(=C/c2cc3c4c(c2)CCCN4CCC3)SC1=S</smiles><smiles>NCCOCCOCCCCCCCl</smiles>

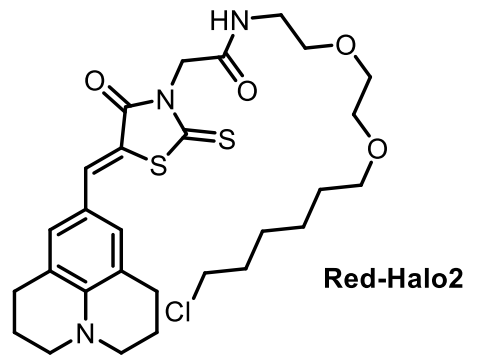

To a stirred solution of $2 \mathrm{a}$ ( $50 \mathrm{mg}, 0.13 \mathrm{mmol}, 1.0 \mathrm{eq}), \mathbf{S 1}$ (36 mg, $0.16 \mathrm{mmol}, 1.2 \mathrm{eq}$ ) and DIPEA $(0.05 \mathrm{~mL}, 0.27 \mathrm{mmol}, 2.0 \mathrm{eq})$ in DCM $(1.5 \mathrm{~mL})$ was added HATU $(51 \mathrm{mg}, 0.13$ $\mathrm{mmol}, 1.0 \mathrm{eq})$ and the reaction was stirred at room temperature overnight in the dark. The mixture was washed with brine and extracted with dichloromethane. The organic layer was dried over $\mathrm{MgSO}_{4}$, filtered and evaporated to dryness and the crude product was purified by column chromatography (EtOAc:DCM, 0:1 to 3:7) to give Red-Halo2 (46 mg, 59\%) as an orange solid. ${ }^{1} \mathrm{H}$ NMR $\left(300 \mathrm{MHz}, \mathrm{CDCl}_{3}\right): 7.57(\mathrm{~s}, 1 \mathrm{H}), 6.94(\mathrm{~s}, 2 \mathrm{H}), 6.42(\mathrm{t}, \mathrm{J}=5.5 \mathrm{~Hz}, 1 \mathrm{H}), 4.76$ $(\mathrm{s}, 2 \mathrm{H}), 3.65-3.41(\mathrm{~m}, 12 \mathrm{H}), 3.32-3.25(\mathrm{~m}, 4 \mathrm{H}), 2.77-2.70(\mathrm{~m}, 4 \mathrm{H}), 2.01-1.90(\mathrm{~m}, 4 \mathrm{H}), 1.81-1.70$ $(\mathrm{m}, 2 \mathrm{H}), 1.64-1.54(\mathrm{~m}, 2 \mathrm{H}), 1.50-1.28(\mathrm{~m}, 4 \mathrm{H}) .{ }^{13} \mathrm{C} \mathrm{NMR}\left(75 \mathrm{MHz}, \mathrm{CDCl}_{3}\right): \delta 193.3,167.6$, 165.3, 145.9, 136.1, 131.2, 121.5, 119.8, 113.4, 71.4, 70.5, 70.2, 69.8, 50.2, 46.7, 45.2, 39.6, 
32.6, 29.6, 27.8, 26.8, 25.5, 21.3. HRMS calcd for $\mathrm{C}_{28} \mathrm{H}_{38} \mathrm{ClN}_{3} \mathrm{O}_{4} \mathrm{~S}_{2} \mathrm{Na}$ : 602.1884. Found: 602.1880. HPLC $97 \%$.

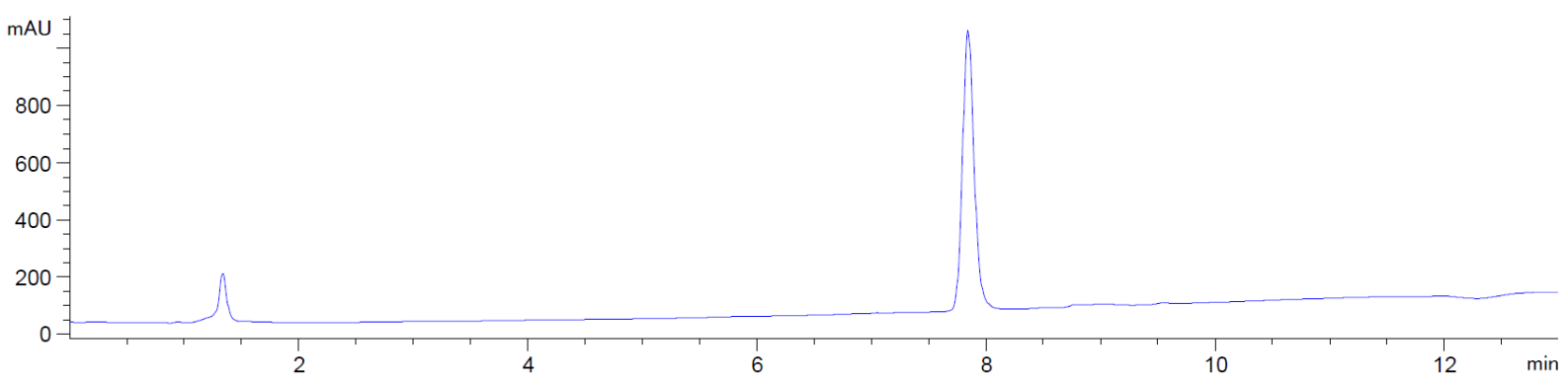

(Z)-N-(2-((6-chlorohexyl)oxy)ethyl)-2-(4-oxo-5-((2,3,6,7-tetrahydro-1H,5H-pyrido[3,2,1ij]quinolin-9-yl)methylene)-2-thioxothiazolidin-3-yl)acetamide Red-Halo2s<smiles>O=C(O)CN1C(=O)/C(=C/c2cc3c4c(c2)CCCN4CCC3)SC1=S</smiles><smiles>NCCCCCCOCCCl</smiles>

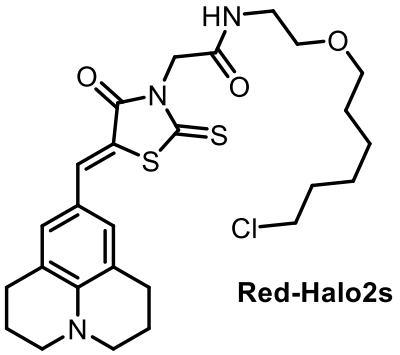

To a stirred solution of $\mathbf{2 a}$ ( $25 \mathrm{mg}, 0.07 \mathrm{mmol}, 1.0 \mathrm{eq}), \mathbf{S 2}(37 \mathrm{mg}, 0.21 \mathrm{mmol}, 3.0 \mathrm{eq}$ ) and DIPEA (0.03 mL, $0.13 \mathrm{mmol}, 2.0 \mathrm{eq})$ in DCM $(1.5 \mathrm{~mL})$ was added HATU (25 mg, 0.07 $\mathrm{mmol}, 1.0 \mathrm{eq})$ and the reaction was stirred at room temperature overnight in the dark. The mixture was washed with brine and extracted with dichloromethane. The organic layer was dried over $\mathrm{MgSO}_{4}$, filtered and evaporated to dryness and the crude product was purified by column chromatography (EtOAc:DCM, 0:1 to 1:3) to give Red-Halo2s (11 mg, 31\%) as an orange solid. ${ }^{1} \mathrm{H}$ NMR $\left(300 \mathrm{MHz}, \mathrm{CDCl}_{3}\right): 7.61(\mathrm{~s}, 1 \mathrm{H}), 6.97(\mathrm{~s}, 2 \mathrm{H}), 6.07(\mathrm{~s}, 1 \mathrm{H}), 4.78(\mathrm{~s}, 2 \mathrm{H})$, 3.55-3.38 (m, 8H), 3.36-3.26 (m, 4H), $2.76(\mathrm{t}, \mathrm{J}=6.5 \mathrm{~Hz}, 4 \mathrm{H}), 2.04-1.91(\mathrm{~m}, 4 \mathrm{H}), 1.83-1.71(\mathrm{~m}$, $2 \mathrm{H}), 1.62-1.50(\mathrm{~m}, 2 \mathrm{H}), 1.48-1.30(\mathrm{~m}, 4 \mathrm{H}) .{ }^{13} \mathrm{C}$ NMR $\left(75 \mathrm{MHz}, \mathrm{CDCl}_{3}\right): \delta 193.2,167.6,165.3$, 146.0, 136.3, 131.3, 121.7, 119.9, 113.4, 71.2, 69.2, 50.2, 47.0, 45.2, 39.6, 32.7, 29.7, 27.8, 26.9, 25.6, 21.3. HRMS calcd for $\mathrm{C}_{26} \mathrm{H}_{34} \mathrm{ClN}_{3} \mathrm{O}_{3} \mathrm{~S}_{2} \mathrm{~K}$ : 574.1362. Found: 574.1358. HPLC 76\%.

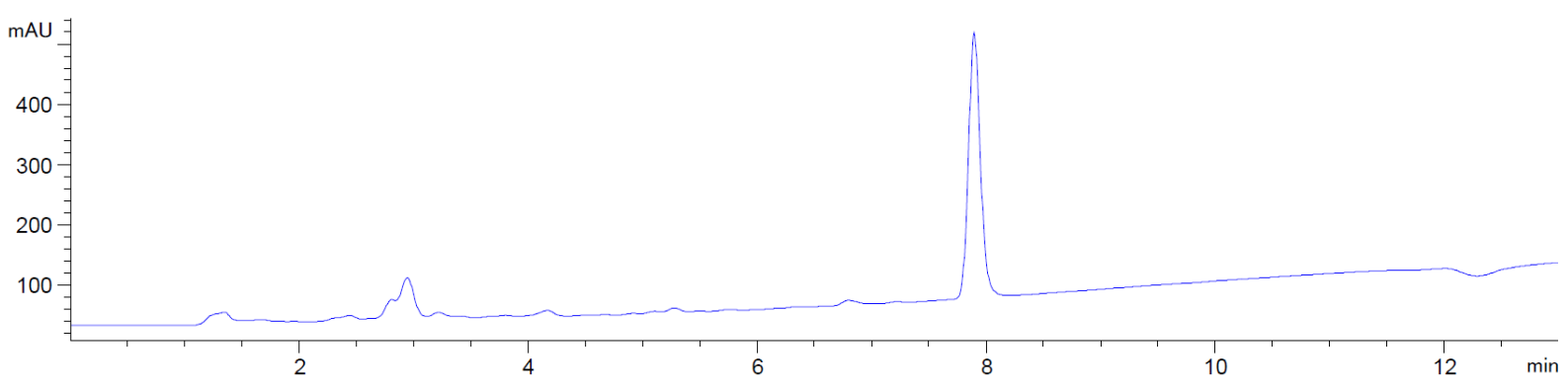



acid $1 \mathrm{~b}$<smiles>CCOC(C)(C)C(=O)O</smiles>

A solution of dimethylamino cinnamaldehyde $(92 \mathrm{mg}, 0.52 \mathrm{mmol}, 1.0 \mathrm{eq}$ ) and rhodanine-3-acetic acid $(100 \mathrm{mg}, 0.52 \mathrm{mmol}, 1.0 \mathrm{eq})$ in ethanol $(7.0 \mathrm{~mL})$ was stirred at $100{ }^{\circ} \mathrm{C}$ overnight in the dark. The mixture was filtered and washed with ethanol to give $\mathbf{1 b}(66 \mathbf{~ m g}$, $36 \%)$ as a blue solid. ${ }^{1} \mathrm{H}$ NMR $\left(300 \mathrm{MHz}\right.$, DMSO- $\left.\mathrm{d}_{6}\right)$ : $13.34(\mathrm{~s}, 1 \mathrm{H}), 7.61-7.51(\mathrm{~m}, 3 \mathrm{H}), 7.34(\mathrm{~d}, \mathrm{~J}$ $=15.0 \mathrm{~Hz}, 1 \mathrm{H}), 6.82(\mathrm{dd}, \mathrm{J}=15.0,12.0 \mathrm{~Hz}, 1 \mathrm{H}), 6.73(\mathrm{~d}, \mathrm{~J}=9.0 \mathrm{~Hz}, 2 \mathrm{H}), 4.68(\mathrm{~s}, 2 \mathrm{H}), 3.01(\mathrm{~s}$, 6H). ${ }^{13} \mathrm{C}$ NMR (75 MHz, DMSO-d 6 ): $\delta$ 192.4, 167.5, 165.6, 151.9, 148.1, 136.2, 130.5, 123.0, 118.2, 118.1, 111.9, 44.9, 39.7. HRMS calcd for $\mathrm{C}_{16} \mathrm{H}_{15} \mathrm{~N}_{2} \mathrm{O}_{3} \mathrm{~S}_{2}$ : 347.0530. Found: 347.0528 . HPLC 95\%.

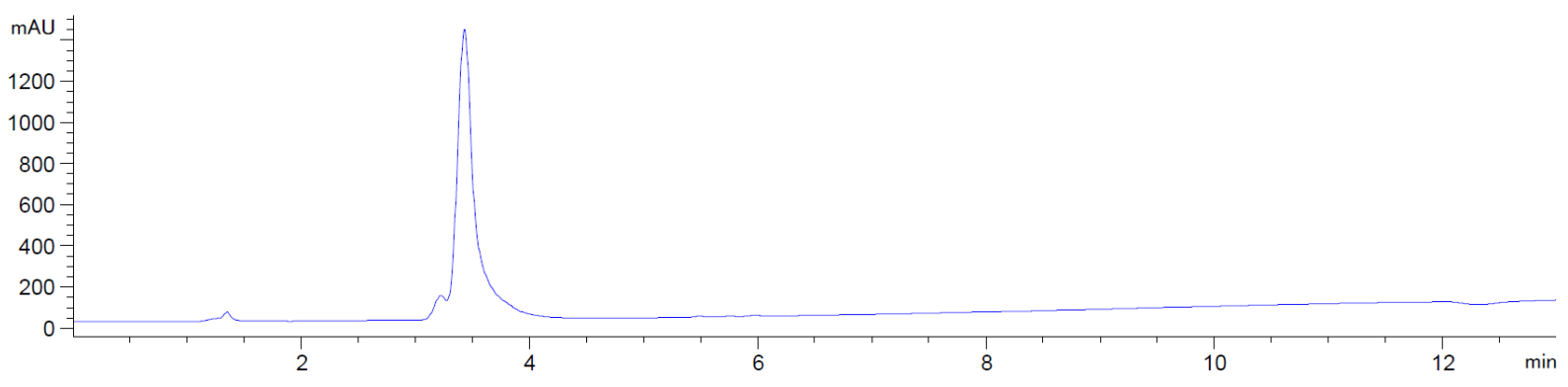

N-(2-(2-((6-chlorohexyl)oxy)ethoxy)ethyl)-2-((Z)-5-((E)-3-(4-

(dimethylamino)phenyl)allylidene)-4-oxo-2-thioxothiazolidin-3-yl)acetamide NIR-Halo1
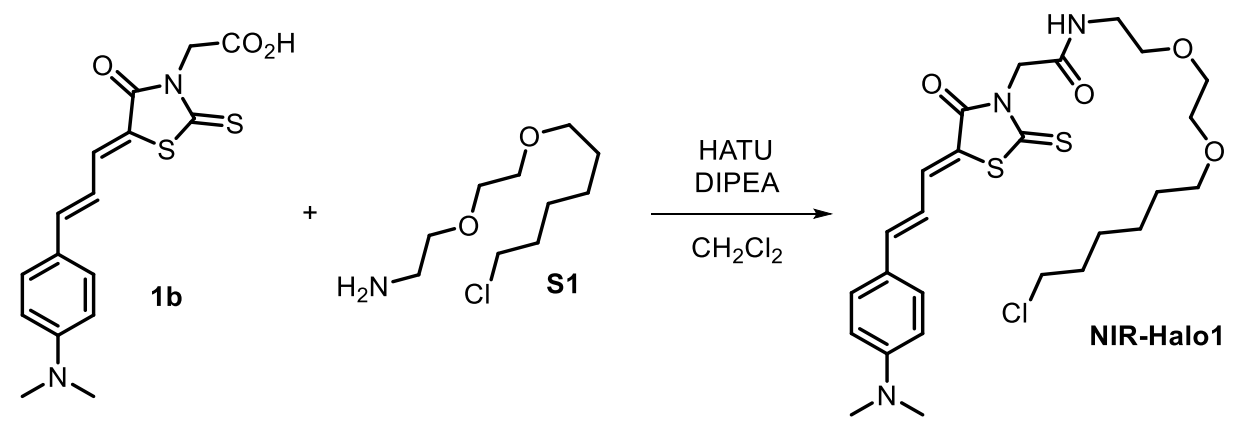

To a stirred solution of $\mathbf{1 b}$ (50 $\mathrm{mg}, 0.14 \mathrm{mmol}, 1.0 \mathrm{eq}), \mathbf{S 1}(39 \mathrm{mg}, 0.17 \mathrm{mmol}, 1.2 \mathrm{eq}$ ) and DIPEA (0.05 mL, $0.29 \mathrm{mmol}, 2.0 \mathrm{eq})$ in DCM $(1.5 \mathrm{~mL})$ was added HATU $(55 \mathrm{mg}, 0.14$ $\mathrm{mmol}, 1.0 \mathrm{eq})$ and the reaction was stirred at room temperature overnight in the dark. The mixture was washed with brine and extracted with dichloromethane. The organic layer was dried over $\mathrm{MgSO}_{4}$, filtered and evaporated to dryness and the crude product was purified by column chromatography (EtOAc:DCM, 0:1 to 3:7) to give NIR-Halo1 (51 mg, 64\%) as a purple solid. ${ }^{1} \mathrm{H}$ NMR $\left(300 \mathrm{MHz}, \mathrm{CDCl}_{3}\right)$ : 7.49-7.35 (m, 3H), $6.99(\mathrm{~d}, \mathrm{~J}=15.0 \mathrm{~Hz}, 1 \mathrm{H}), 6.68-6.61(\mathrm{~m}$, $2 \mathrm{H}), 6.55-6.48(\mathrm{~m}, 1 \mathrm{H}), 6.45(\mathrm{t}, \mathrm{J}=5.5 \mathrm{~Hz}, 1 \mathrm{H}), 4.72(\mathrm{~s}, 2 \mathrm{H}), 3.64-3.42(\mathrm{~m}, 12 \mathrm{H}), 3.03(\mathrm{~s}, 6 \mathrm{H})$, 1.81-1.70 (m, 2H), 1.65-1.54 (m, 2H), 1.50-1.29 (m, 4H). $\left.{ }^{13} \mathrm{C} \mathrm{NMR} \mathrm{(75} \mathrm{MHz,} \mathrm{CDCl}_{3}\right): \delta$ 192.4, 166.6, 165.1, 151.9, 146.8, 135.5, 130.1, 123.4, 119.8, 118.1, 112.0, 71.4, 70.5, 70.2, 69.7, 
46.6, 45.2, 40.2, 39.6, 32.6, 29.5, 26.8, 25.5. HRMS calcd for $\mathrm{C}_{26} \mathrm{H}_{36} \mathrm{ClN}_{3} \mathrm{O}_{4} \mathrm{~S}_{2} \mathrm{Na}$ : 576.1728. Found: 576.1724. HPLC 83\%.

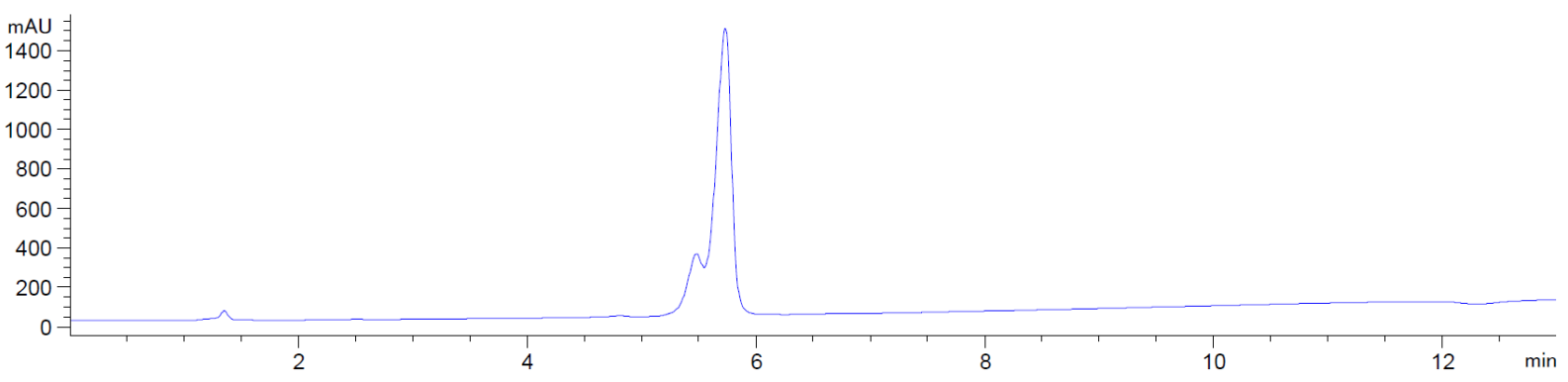

(E)-3-(2,3,6,7-tetrahydro-1H,5H-pyrido[3,2,1-ij]quinolin-9-yl)acrylaldehyde S3<smiles>O=Cc1cc2c3c(c1)CCCN3CCC2</smiles>

To a suspension of (1,3-dioxolan-2-ylmethyl)triphenylphosphonium bromide (1070 $\mathrm{mg}, 2.48 \mathrm{mg}, 5.0 \mathrm{eq})$ in anhydrous THF $(16 \mathrm{~mL})$ was added sodium tert-butoxide $(2.0 \mathrm{M}$ in THF, $0.99 \mathrm{~mL}, 1.99 \mathrm{~mL}, 4.0 \mathrm{eq}$ ) and the reaction was stirred $30 \mathrm{~min}$ at room temperature. 9Julolidinecarboxaldehyde $(100 \mathrm{mg}, 0.50 \mathrm{mmol}, 1.0 \mathrm{eq})$ was next added and the mixture was stirred at room temperature overnight. The reaction was quenched with water, extracted with ethyl acetate and washed with $\mathrm{HCl}(1 \mathrm{M})$ and brine. The organic layer was dried over $\mathrm{MgSO}_{4}$, filtered and evaporated to dryness and the crude product was purified by column chromatography (EtOAc:Cyclohexane, 0:1 to 3:7) to give $\mathbf{S 3}$ (69 $\mathrm{mg}, 61 \%$ ) as a yellow solid. ${ }^{1} \mathbf{H}$ NMR $\left(300 \mathrm{MHz} \mathrm{CDCl}_{3}\right): 9.53(\mathrm{~d}, \mathrm{~J}=8.0 \mathrm{~Hz}, 1 \mathrm{H}), 7.26(\mathrm{~d}, \mathrm{~J}=15.5 \mathrm{~Hz}, 1 \mathrm{H}), 7.00(\mathrm{~s}, 2 \mathrm{H}), 6.46$ $(\mathrm{dd}, \mathrm{J}=15.5,8.0 \mathrm{~Hz}, 1 \mathrm{H}), 3.30-3.20(\mathrm{~m}, 4 \mathrm{H}), 2.76-2.70(\mathrm{~m}, 4 \mathrm{H}), 2.04-1.88(\mathrm{~m}, 4 \mathrm{H}) .{ }^{13} \mathrm{C}$ NMR $\left(75 \mathrm{MHz} \mathrm{CDCl}_{3}\right): \delta 193.7,154.6,145.8,128.3,122.8,121.0,120.8,50.0,27.8,21.5$. HRMS calcd for $\mathrm{C}_{15} \mathrm{H}_{18} \mathrm{NO}: 228.1383$. Found: 228.1384 .

\section{2-((Z)-4-oxo-5-((E)-3-(2,3,6,7-tetrahydro-1H,5H-pyrido[3,2,1-ij]quinolin-9-yl)allylidene)-2-} thioxothiazolidin-3-yl)acetic acid $2 b$

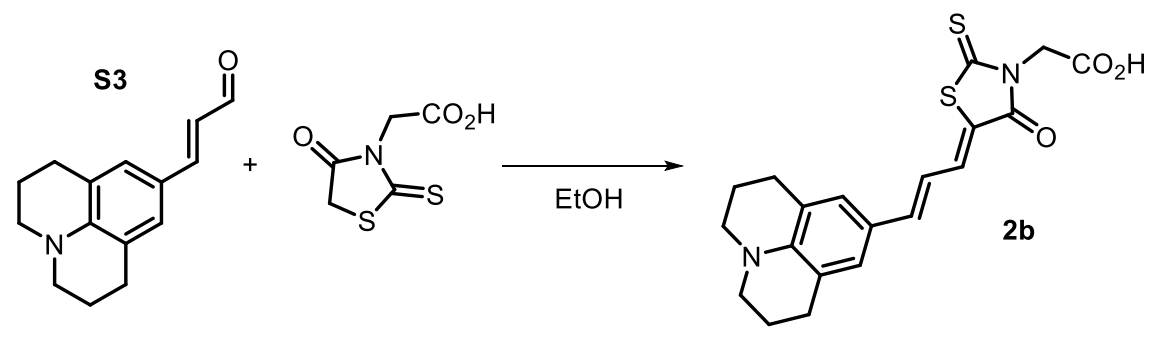

A solution of $\mathbf{S 3}(69 \mathrm{mg}, 0.30 \mathrm{mmol}, 1.0 \mathrm{eq})$ and rhodanine-3-acetic acid (64 mg, 0.33 $\mathrm{mmol}, 1.1 \mathrm{eq})$ in ethanol $(3.0 \mathrm{~mL})$ was stirred at $100{ }^{\circ} \mathrm{C}$ overnight in the dark. The mixture was filtered and washed with ethanol to give $\mathbf{2 b}(64 \mathrm{mg}, 53 \%)$ as a purple solid. ${ }^{1} \mathbf{H}$ NMR (300 MHz, DMSO-d 6 ): $7.51(\mathrm{~d}, \mathrm{~J}=12.0 \mathrm{~Hz}, 1 \mathrm{H}), 7.19(\mathrm{~d}, \mathrm{~J}=14.5 \mathrm{~Hz}, 1 \mathrm{H}), 7.12(\mathrm{~s}, 2 \mathrm{H}), 6.69$ (dd, J = 14.5, $12.0 \mathrm{~Hz}, 1 \mathrm{H}), 4.63(\mathrm{~s}, 2 \mathrm{H}), 3.25(\mathrm{t}, \mathrm{J}=6.0 \mathrm{~Hz}, 4 \mathrm{H}), 2.68(\mathrm{t}, \mathrm{J}=6.0 \mathrm{~Hz}, 4 \mathrm{H}), 1.92-1.78(\mathrm{~m}$, 
4H). ${ }^{13} \mathrm{C}$ NMR (75 MHz, DMSO-d 6 ): $\delta$ 192.1, 167.5, 165.5, 148.6, 145.3, 136.4, 128.1, 122.0, 120.7, 117.0, 116.7, 49.3, 45.2, 27.0, 20.9. HRMS calcd for $\mathrm{C}_{20} \mathrm{H}_{19} \mathrm{~N}_{2} \mathrm{O}_{3} \mathrm{~S}_{2}$ : 399.0843. Found: 399.0841. HPLC $97 \%$.

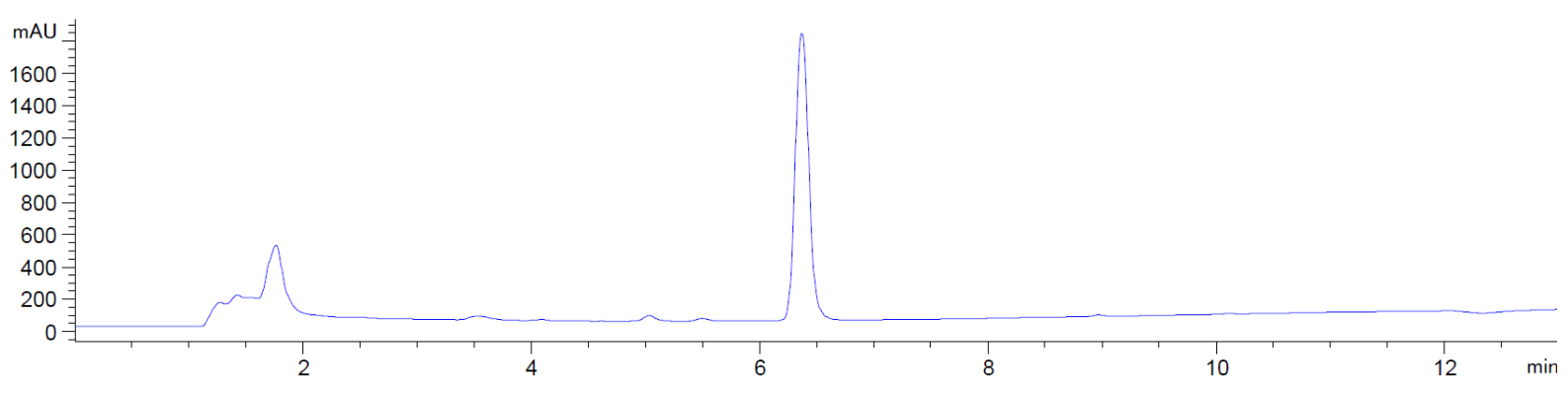

$\mathrm{N}-(2-(2-((6-$ chlorohexyl)oxy)ethoxy)ethyl)-2-((Z)-4-oxo-5-((E)-3-(2,3,6,7-tetrahydro-1H,5Hpyrido[3,2,1-ij]quinolin-9-yl)allylidene)-2-thioxothiazolidin-3-yl)acetamide NIR-Halo2<smiles>O=C(O)CN1C(=O)/C(=C/C=C/c2cc3c4c(c2)CCCN4CCC3)SC1=S</smiles>

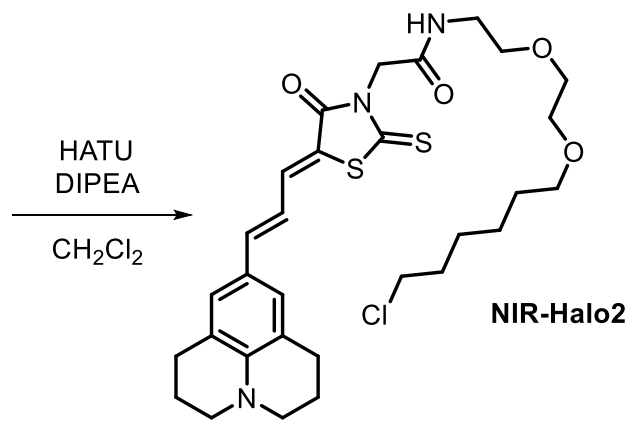

To a stirred solution of $\mathbf{2 b}$ ( $30 \mathrm{mg}, 0.07 \mathrm{mmol}, 1.0 \mathrm{eq}), \mathbf{S 1}(20 \mathrm{mg}, 0.09 \mathrm{mmol}, 1.2 \mathrm{eq}$ ) and DIPEA (0.01 mL, $0.15 \mathrm{mmol}, 2.0 \mathrm{eq})$ in DCM $(1.0 \mathrm{~mL})$ was added HATU (28 $\mathrm{mg}, 0.14$ $\mathrm{mmol}, 1.0 \mathrm{eq}$ ) and the reaction was stirred at room temperature overnight in the dark. The mixture was washed with brine and extracted with dichloromethane. The organic layer was dried over $\mathrm{MgSO}_{4}$, filtered and evaporated to dryness and the crude product was purified by column chromatography (EtOAc:DCM, 0:1 to 3:7) to give NIR-Halo2 (13 mg, 29\%) as a purple solid. ${ }^{1} \mathrm{H}$ NMR $\left(300 \mathrm{MHz}, \mathrm{CDCl}_{3}\right): 7.47(\mathrm{~d}, \mathrm{~J}=12.0 \mathrm{~Hz}, 1 \mathrm{H}), 7.05-6.89(\mathrm{~m}, 3 \mathrm{H}), 6.46(\mathrm{dd}, \mathrm{J}=$ $14.5,12.0 \mathrm{~Hz}, 1 \mathrm{H}), 6.32(\mathrm{t}, \mathrm{J}=5.5 \mathrm{~Hz}, 1 \mathrm{H}), 4.74(\mathrm{~s}, 2 \mathrm{H}), 3.65-3.42(\mathrm{~m}, 12 \mathrm{H}), 3.26(\mathrm{t}, \mathrm{J}=6.0 \mathrm{~Hz}$, $4 \mathrm{H}), 2.74(\mathrm{t}, \mathrm{J}=6.0 \mathrm{~Hz}, 4 \mathrm{H}), 2.00-1.91(\mathrm{~m}, 4 \mathrm{H}), 1.82-1.71(\mathrm{~m}, 2 \mathrm{H}), 1.67-1.53(\mathrm{~m}, 2 \mathrm{H}), 1.50-1.32$ (m, 4H). ${ }^{13} \mathrm{C}$ NMR $\left(75 \mathrm{MHz}, \mathrm{CDCl}_{3}\right): \delta 192.4,166.6,165.2,147.6,145.5,136.2,128.0,122.5$, 121.4, 118.5, 117.2, 71.5, 70.6, 70.2, 69.8, 50.2, 46.8, 45.2, 39.7, 32.7, 29.6, 27.8, 26.8, 25.6, 21.6. HRMS calcd for $\mathrm{C}_{30} \mathrm{H}_{40} \mathrm{CIN}_{3} \mathrm{O}_{4} \mathrm{~S}_{2} \mathrm{~K}: 644.1780$. Found: 644.1777. HPLC 99\%.

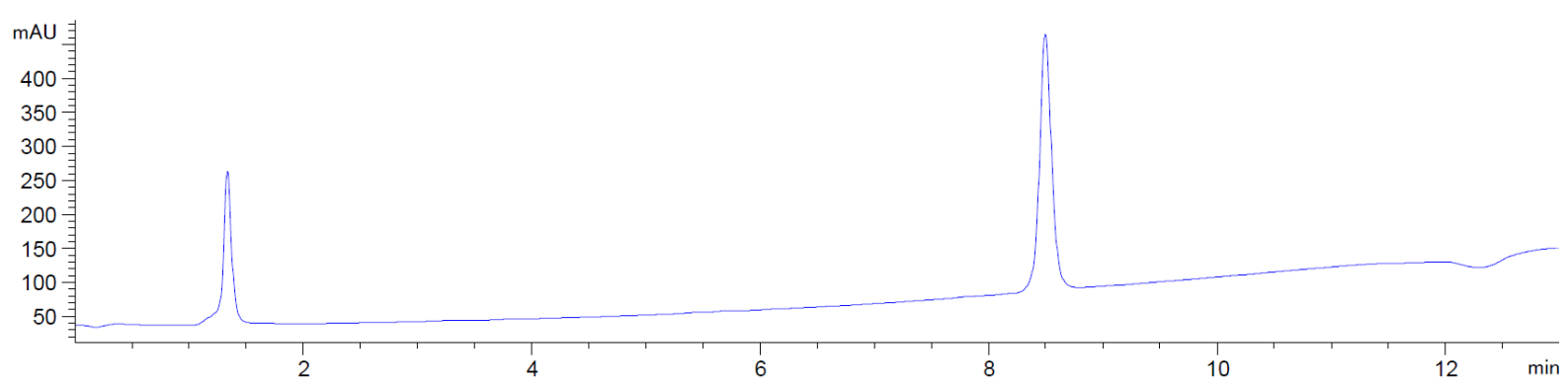




\section{NMR spectra}

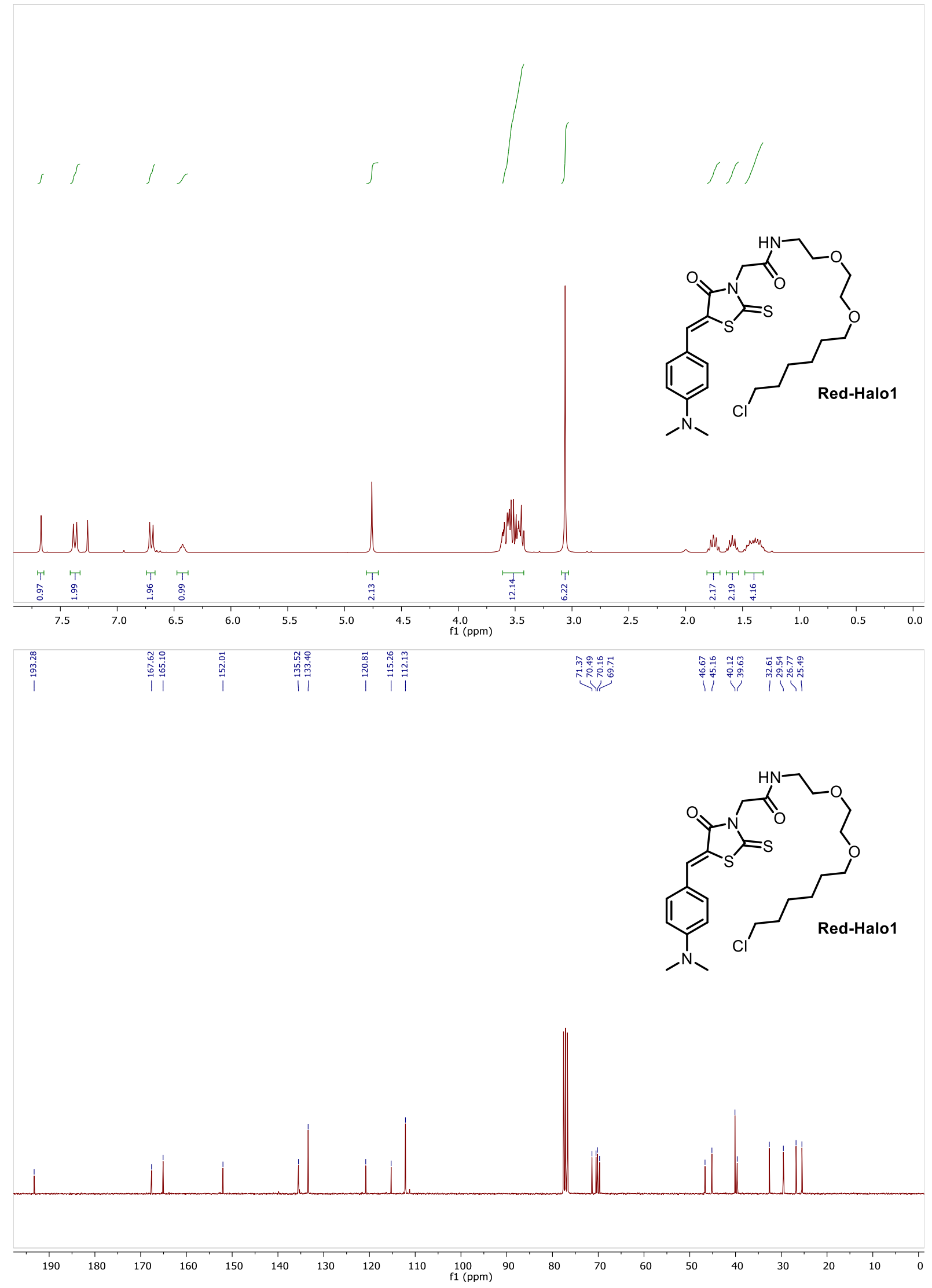




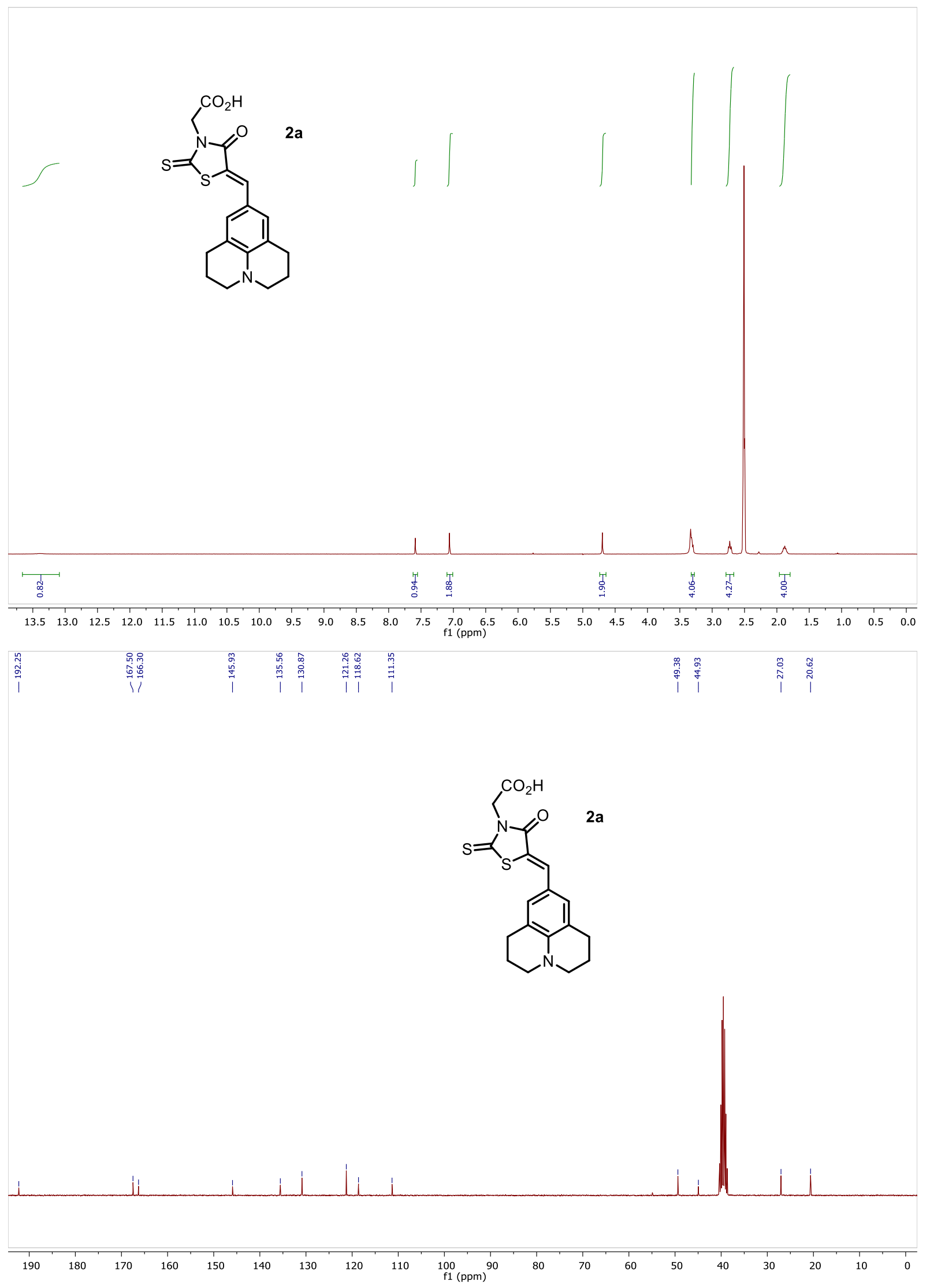

S-13 


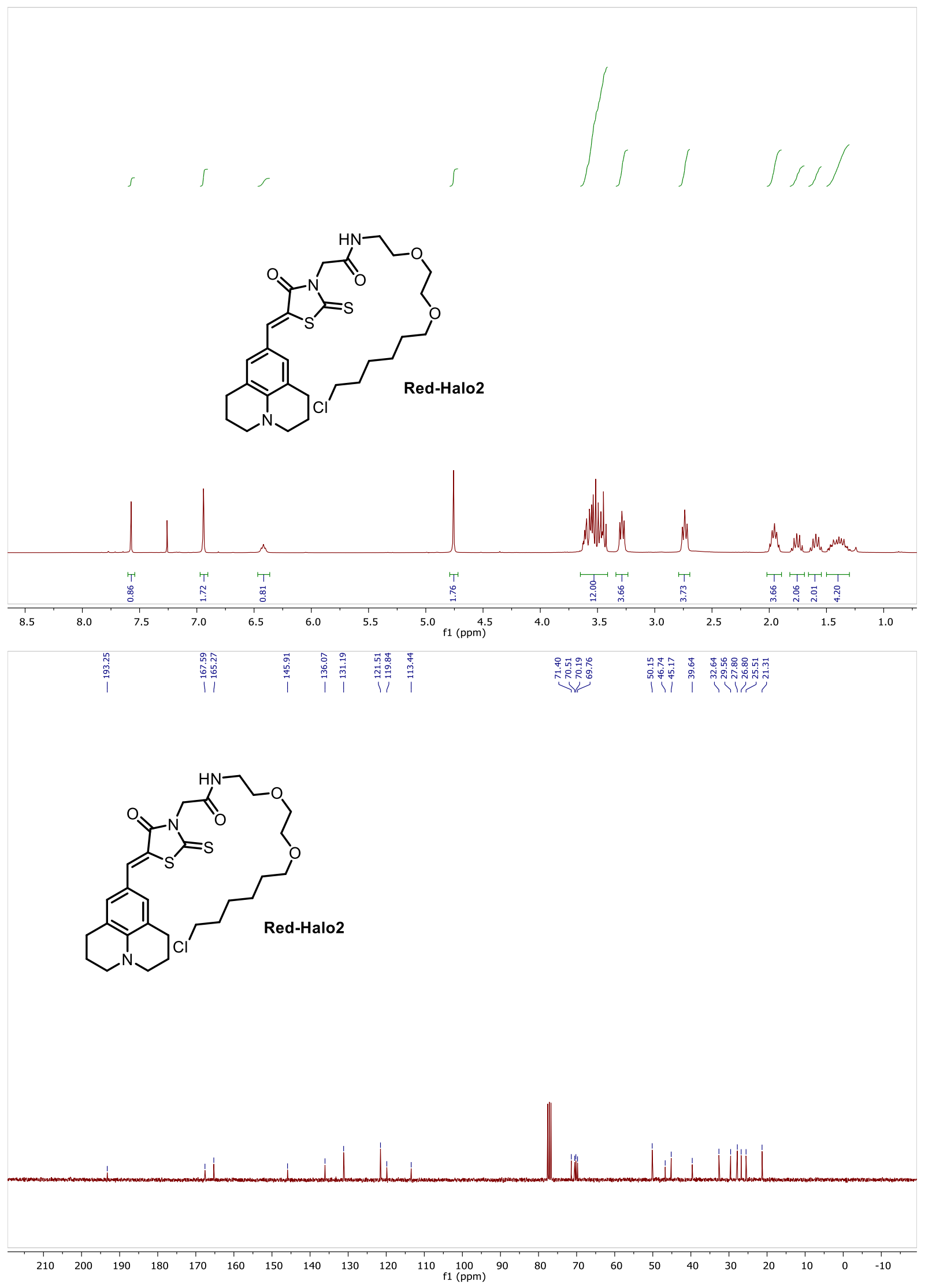

S-14 


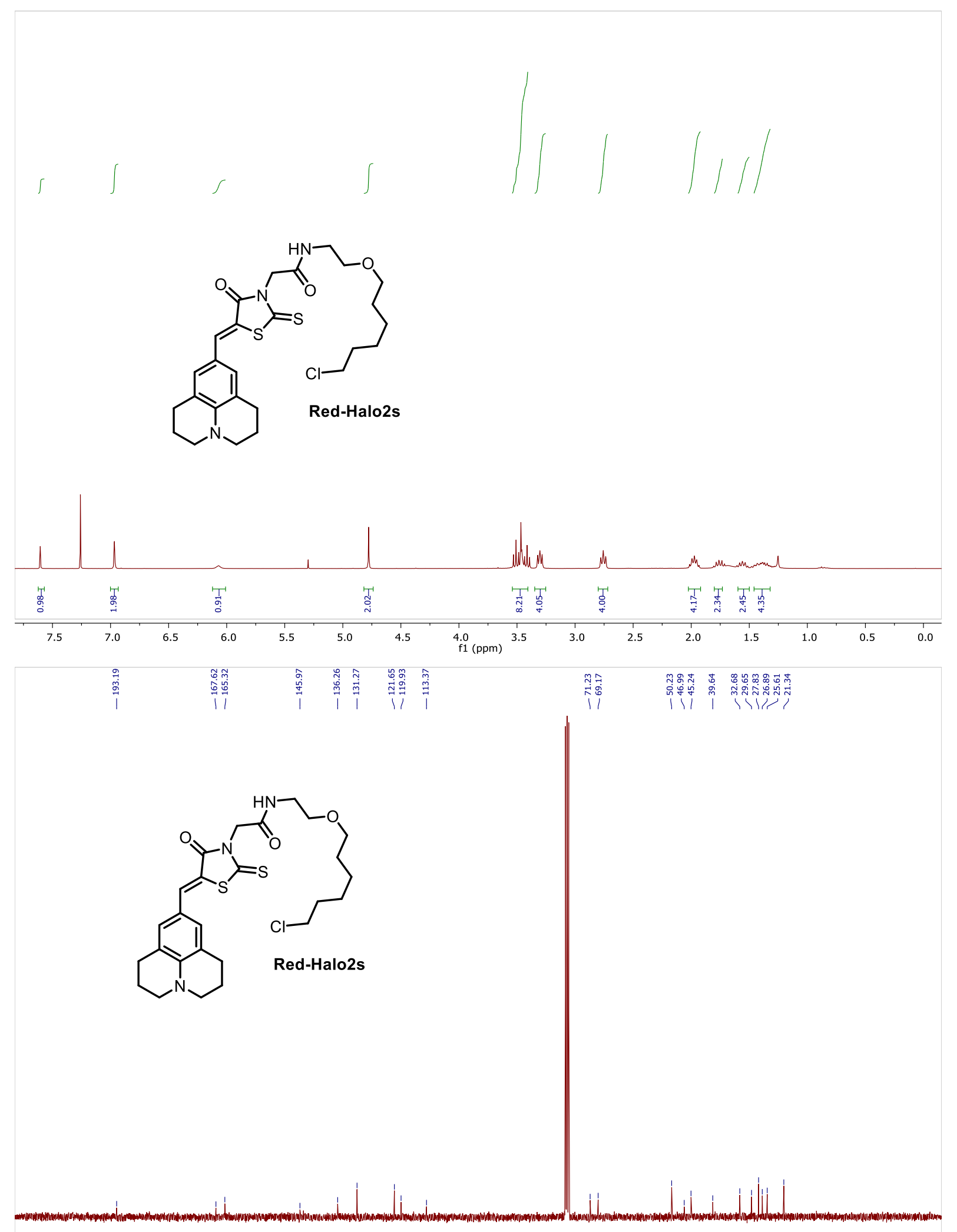

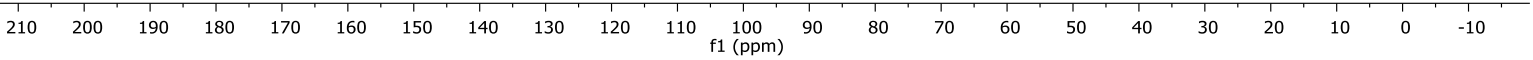




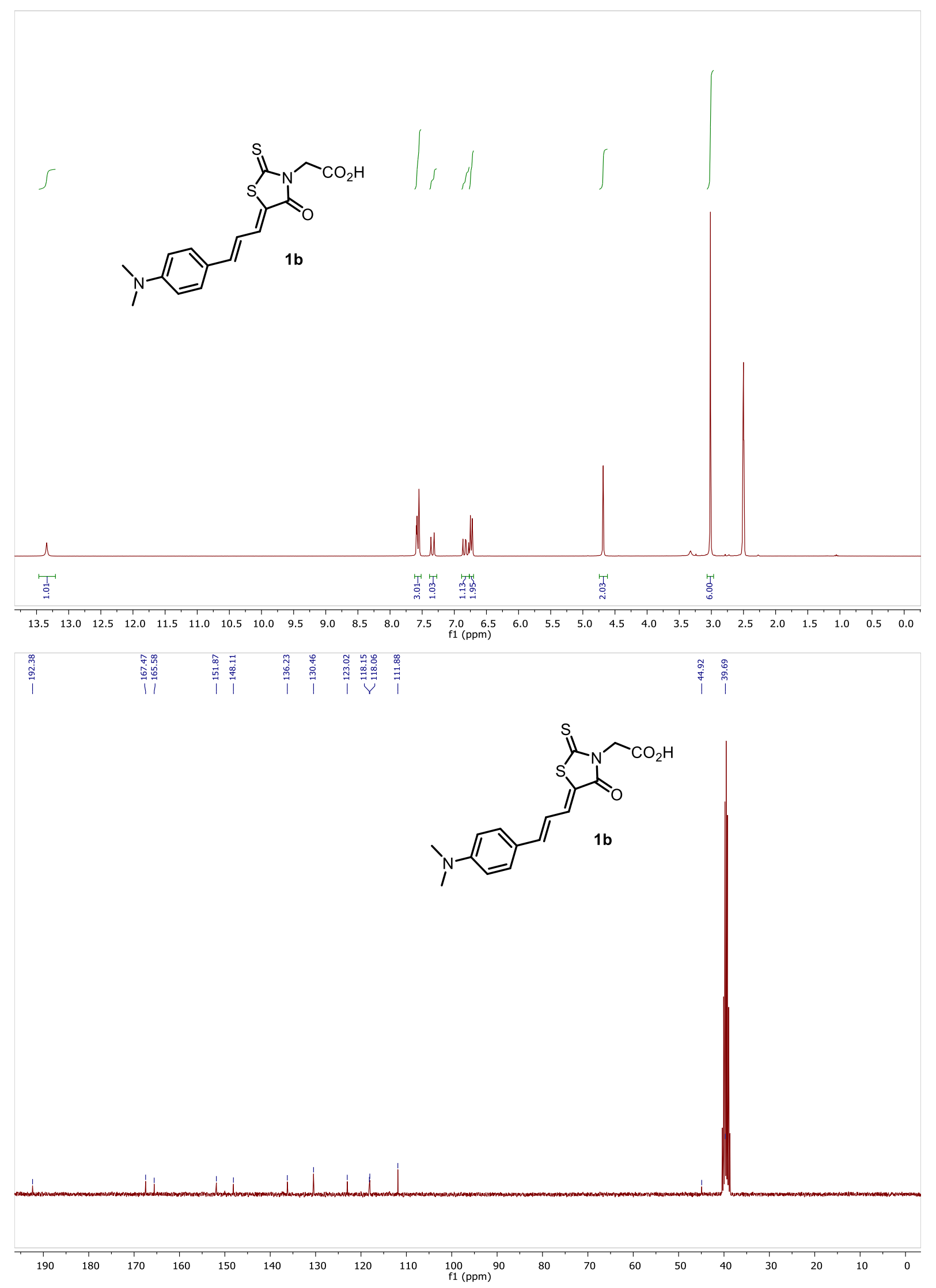




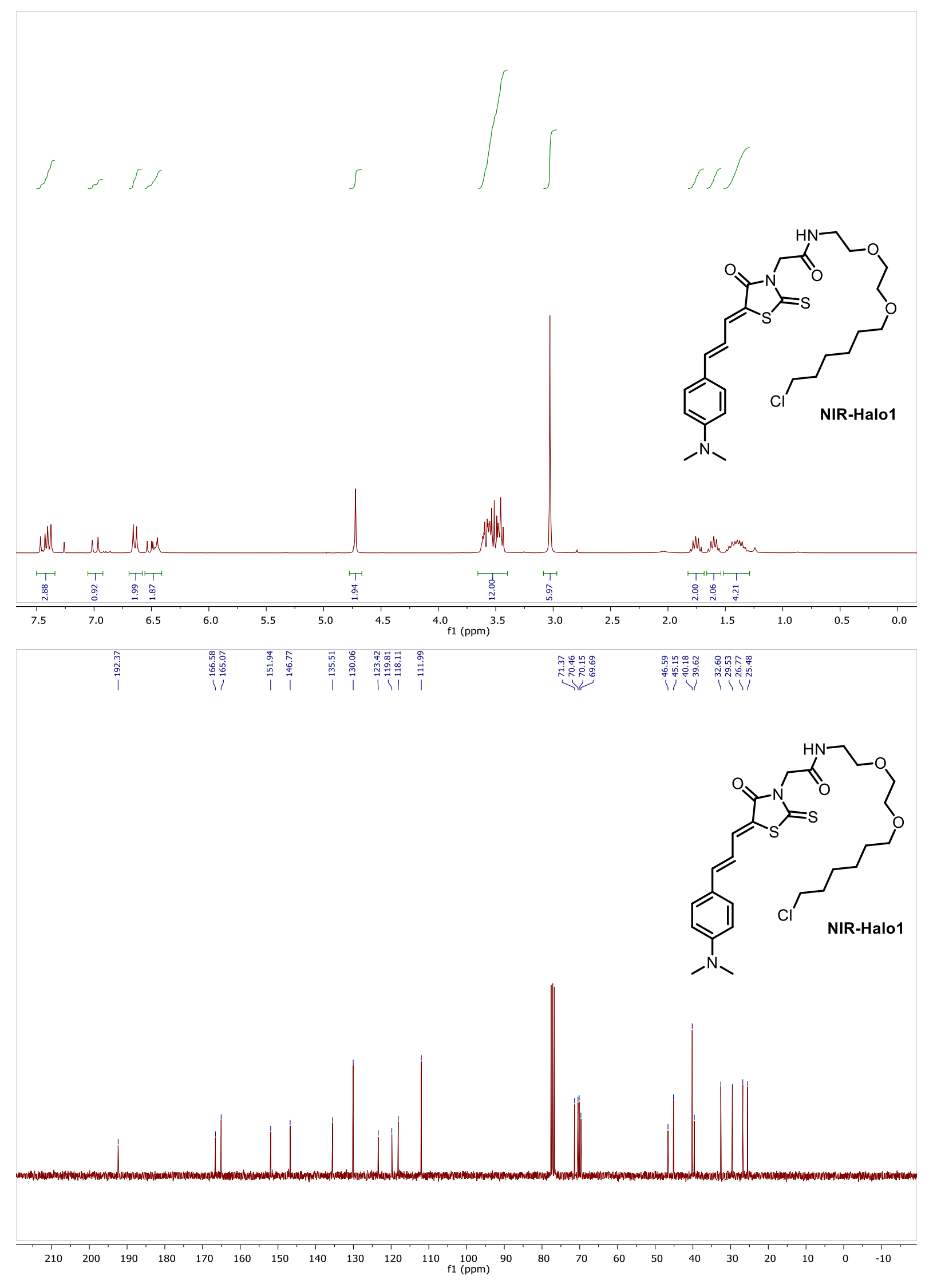




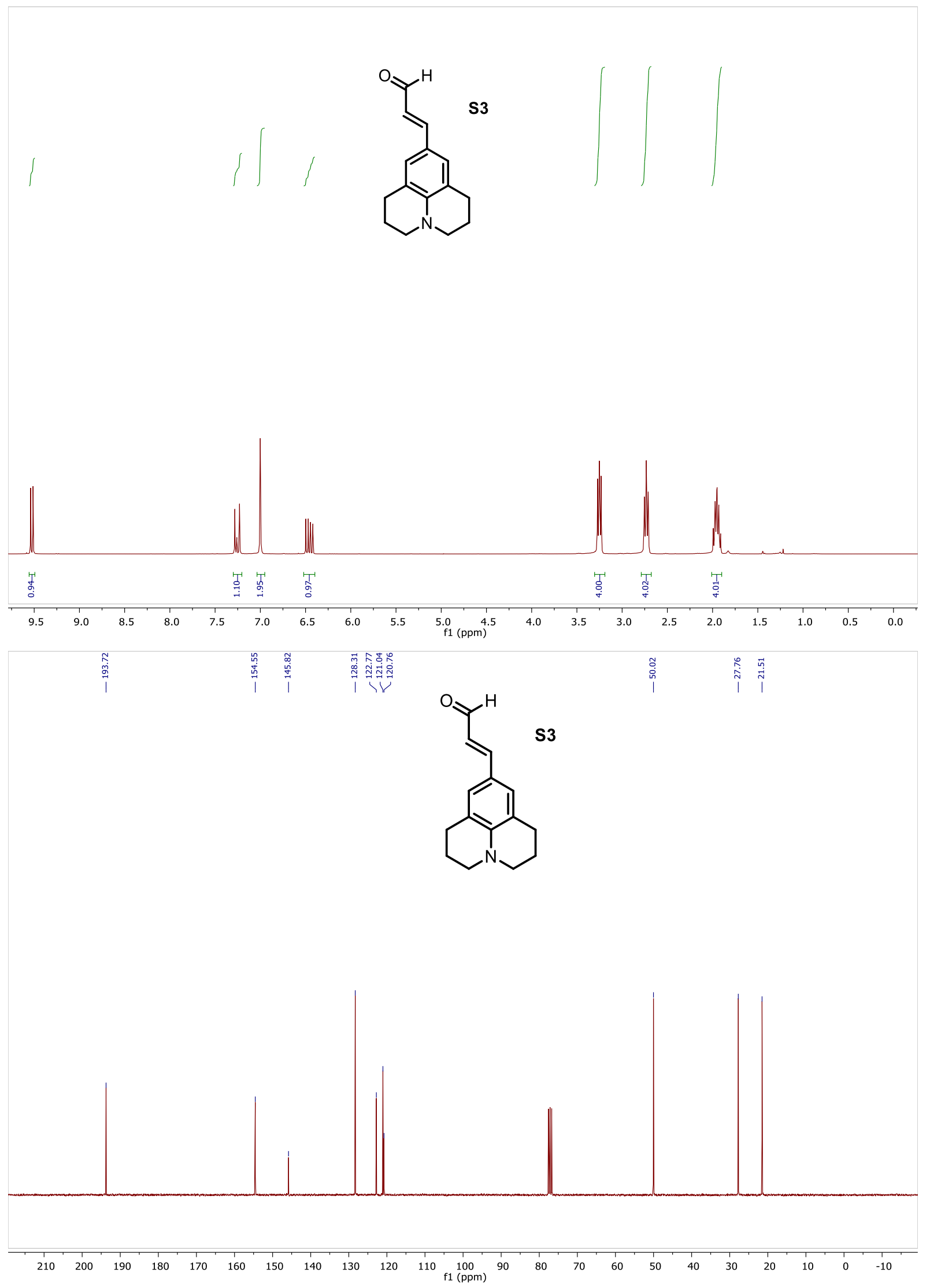

S-18 


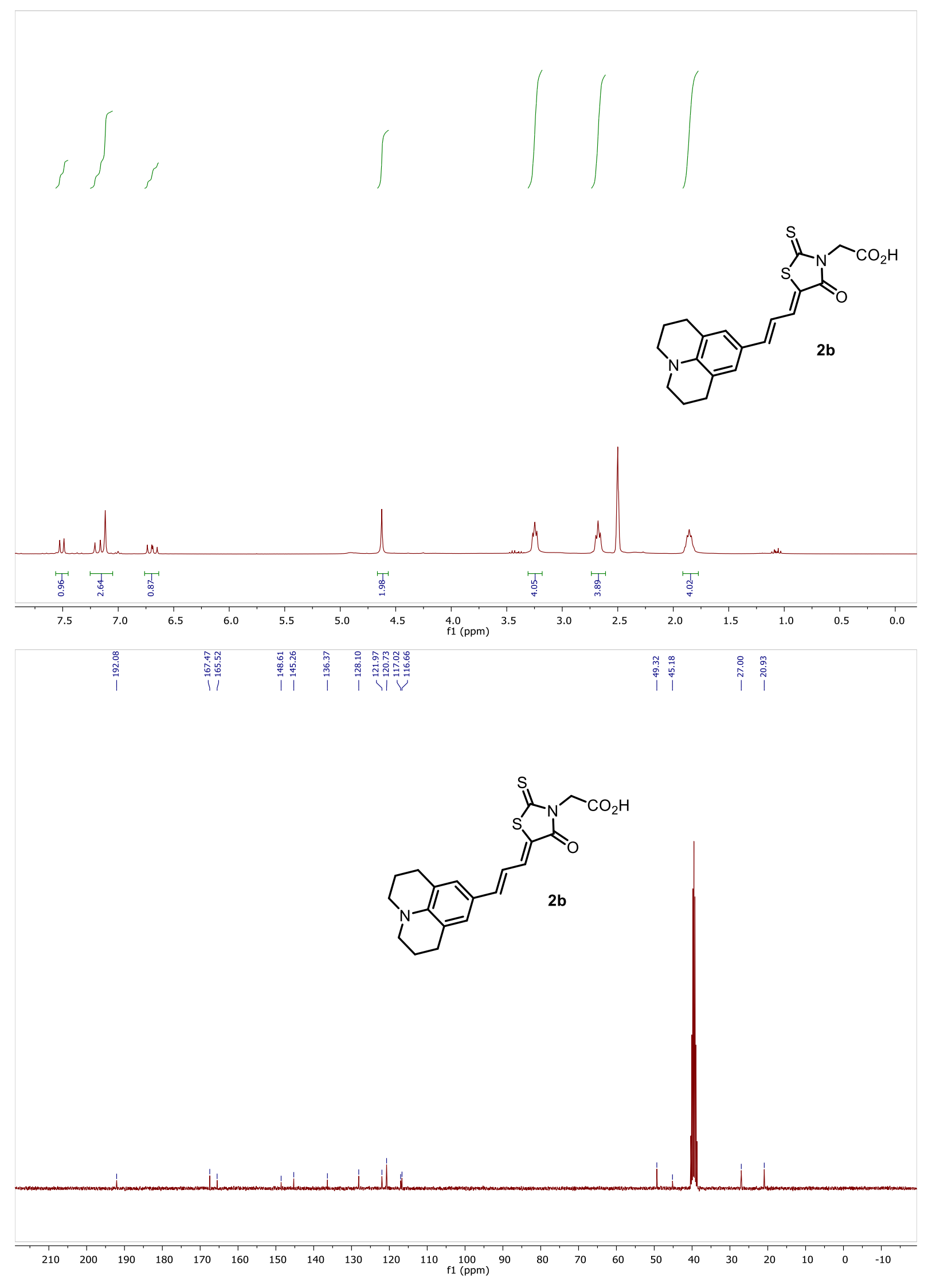




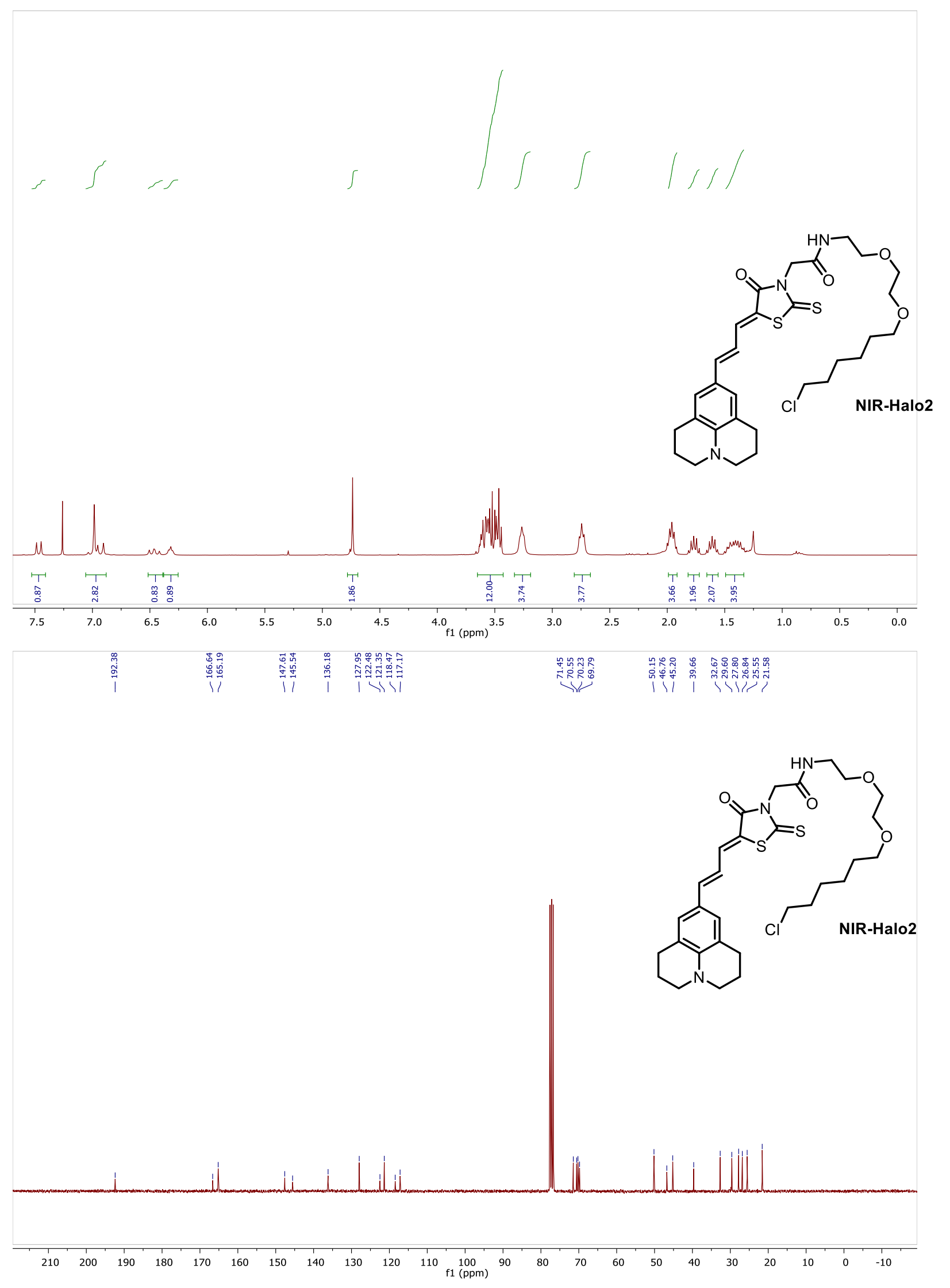

\section{References}

1. Brouwer, A. M. Pure Appl. Chem. 2011, 83 (12), 2213-2228.

2. Rekaï, E. D.; Baudin, J. B.; Jullien, L.; Ledoux, I.; Zyss, J.; Blanchard-Desce, M. Chem. 
Eur. J. 2001, 7 (20), 4395-4402.

3. Singh, V.; Wang, S.; Kool, E. T. J. Am. Chem. Soc. 2013, 135 (16), 6184-6191. 
